\title{
El mito de Europa en los mosaicos hispano-romanos. Análisis iconográfico e interpretativo
}

\author{
G. López Monteagudo * y M.P. San Nicolás Pedraz **
}

Mencionado numerosas veces en los textos antiguos (Hom. II. XIV 321322; Hesiod. Theog. 357 y fragm. 52; Herod. Hist. I 2 y IV 45; Mosch. II 1 152; Ovid. Met. II 836-875; Fast. V 603-620; Her. IV 55; Ars am. I 23 y VI 103-107; Hor. Od. III 25 ss.; Nonn. Dion. I 46 ss.), el mito de Europa se sitúa en la antigua Fenicia y relata cómo Europa, hija de Telefasa y de Agenor o Fenix, rey de Fenicia, estando un día recogiendo flores junto a sus compañeras en las playas de Tyro o de Sidón (Mosch. 1134 y 37), reparó en un toro de color blanco que pastaba entre los rebaños de su padre. La joven princesa, entre asustada y maravillada, se siente atraída por un animal tan bello y apacible y, no sospechando que se trata del propio Zeus que se ha metamorfoseado en toro para seducirla, le acaricia, le ofrece flores como pasto, le adorna con guirnaldas y termina por subir a su grupa, momento que aprovecha el animal para salir corriendo hacia el mar y dirigirse a Gortyna, en la costa sur de Creta, o a Tebas en Beocia, donde como colofón de toda una secuencia de seducción amorosa, que tiene su cenit durante la travesía marina, se consuma la unión junto a una fuente y bajo un plátano que, en recuerdo de estos amores, obtuvo el privilegio de no perder nunca las hojas ${ }^{1}$.

* CSIC. Madrid.

** UNED. Madrid.

1 En los tiempos míticos Gortyna fue la ciudad más importante de Creta, después de Knossos, de la que estaba separada por el río Pothereus (Str. X 476 y 478 ; Vitr. de arch. 14,40). Situada al $\mathrm{N}$. del rio Lethaeos en la cima de una colina, la ciudad llevó sucesivamente los nombres de Ellotis, Larissa, Cremnia y finalmente de Gortyna, nombre que según la leyenda (Steph. Byz., en Luc. dea syr. 6) recibida por los cretenses era debido al héroe Gortys, hijo de Radamantis, nacido de la unión de Zeus y de Europa, o de Tegeates en opinión de los Arcadios (Paus. VIII 53,4 ). Por su parte, Estrabón $(X 476,8)$ relata que Gortyna fue una de las ciudades fundadas por Minos, el otro hijo de Europa y Zeus. 
Según la tradición el rey de Fenicia habría enviado a su hijo Cadmos y a algunos de sus compañeros a buscar a Europa, arrivando en su recorrido a Delfos donde el oráculo le aconsejó dejarse guiar por una vaca cuyos flancos estaban marcados por un signo blanco parecido a un creciente lunar (Suit. Pyth. 225-228; Museion frag. 18; Paus. Descr. Graec. IX 19,4; Nonn. Dion. I 138-140, IV 286-306). Cadmos no halló a su hermana pero, llegado al lugar donde la vaca se echó en el suelo, consideró finalizado su periplo y fundó la ciudad de Tebas. De esta forma, el mito de Europa sirve para justificar la expansión de los hombres del Este, que dieron el nombre de Europa a todas las tierras del Oeste recorridas en su búsqueda. Europa es pues un topos, ya que se convierte en epónimo de un continente, y el periplo cadmeo viene a ser un relato de carácter etiológico.

Las fuentes griegas de época arcáica y clásica centran su interés en las consecuencias históricas y geográficas del mito de Europa (Hom. II. XIV 321; Hesiod. Theog. 357; Fragm. 52; Herod. Hist. I, 2, IV 45), al contrario de la literatura helenística que abunda más en el contenido lírico y erótico de los detalles anecdóticos del rapto (Mosch. II 1-152). Unas y otras ejercen su influencia en Ovidio, que en el siglo I d.C. inmortaliza en varias de sus obras la leyenda de Europa (Met. II 850-875; Fast. V 603620; Ars. Am. I 23, VI 103-107; Her. IV 55), ligando la hierogamia con el nacimiento de una nueva zona geográfica: Europa, contrapuesta a Asia y Africa ${ }^{2}$. Ovidio no insiste en el final trágico de la princesa sidonia, traiccionada por Zeus que la abandona después de consumar su unión amorosa de la que nacen dos hijos: Minos y Radamantis (Hom. II. XIV 321; Plat. Min. 318; Eur. Cret. frag. 475; Diod. IV 60; Nonn. Dion. I 355) y quizás también Sarpedón (Hesiod. frag. 39, en Herod. Hist. I 173), adoptados todos por Asterion, rey de Creta, después de su matrimonio con Europa. Sí lo hace Horacio (Od. III 27) que, basándose en el relato de Moschos (II 154-161), convierte el arrepentimiento y el castigo invocado por la heroína en una tragedia clásica con un final de gran interés histórico-geográfico, ya que Europa se convierte en epónimo de un continente cuando Venus, después de anunciarle su abandono por Zeus, le hace una promesa etiológica: «... tua sectus orbis / nomina ducet " (Hor. Od. III 27, 67, 75-76).

El carácter etiológico que la literatura latina da al mito de Europa ya se encuentra en la tradición antigua de origen fenicio (Luc. Dea syria 4), que en época tardía hacía de Europa una diosa de la luna o de la tarde, es

2 Ch. Ceausescu, Un topos de la littérature antique: l'eternelle guerre entre l'Europe et l'Asie, Latomus L, 1991, 327-331. 
decir, del ocaso o lo que es lo mismo, de aquella zona por donde se pone el sol. El mismo nombre de Europa tiene también un sentido etiológico puesto que etimológicamente deriva del epíteto euroeis o euros, que significa "sombrío" o "tenebroso", y en este sentido para algunos autores Europa sería la diosa de la oscuridad y por extensión el epónimo del país del ocaso que se encuentra a partir del Helesponto, es decir de Occidente (Himno a Apolo Pytias 46 ss; 73; 113; Eust. Comm. ad Dion. Perieg. 270). Como ya se ha apuntado, la historia de Europa, al igual que tantos otros mitos y entre ellos el de Cadmos, no es más que una leyenda de carácter etiológico, elaborada desde el siglo VIII a.C., para justificar la colonización o expansión hacia Occidente de gentes de origen oriental ${ }^{3}$. En este contexto cobra un enorme interés el relato de Herodoto (l 1-2), según el cual varios griegos, seguramente cretenses, habian arribado a la costa fenicia, a Tyro, y habían raptado a la hija del rey, Europa, en venganza por el anterior secuestro de lo por los tyrios. Muy parecido es el relato de Johannes Malala (Chron. II 34), autor del siglo VI d.C., acerca de cómo los tyrios aún en su tiempo recordaban a Europa en la "tarde infausta", haciéndose eco del mito clásico sobre el rapto de la princesa. Narra que cuando en Tyro reinaba Agenor, padre de Europa, la ciudad sufrió la invasión de Tauros, rey de Creta, que surgiendo del mar por sorpresa y aprovechando la ausencia del rey fenicio y de su hijo, saqueó la ciudad e hizo gran número de prisioneros, entre los que se encontraba la princesa Europa ${ }^{4}$.

En la zona peninsular de Grecia y en las islas del mar Egeo Europa aparece asociada al medio marino, siendo evocada como una diosa del mar. Así Hesiodo (Theog. 357) la presenta como hija de Oceanos y Tetis; Pindaro (Pyth. IV 44) y Apolonio de Rodas (Argon. I 181) la hacian pasar por hija de Tityos, esposa de Poseidón y madre de Eufemos, uno de los argonautas. Por el contrario, en la Grecia continental Europa era una diosa terrestre inseparable del periplo también de carácter etiológico de Cadmos, como medio de justificar la fundación de la ciudad de Tebas y la progresión de las gentes del Este hacia Occidente.

De la gran aceptación que el mito de Europa tuvo en el Mediterráneo, desde el siglo VII a.C. hasta época tardía, dan testimonio las numerosas representaciones existentes de las diversas fases del mito, aunque las más abundantes hagan alusión a la travesía marina, es decir, al rapto

\footnotetext{
3 Y. Lehmann-G. Freyburger, Morphologie et étiologie du mythe d'Europe chez les auteurs latins du ler siécle av. J.C., Actes APLAES, 1992, 62-64.

4 S. RIBICCHINI, Flebili dee fenicie, RSF 28, 1995, 13-14.
} 
propiamente dicho. El tema fué ampliamente tratado por los artistas griegos y romanos en relieves, cerámica, terracotas, pintura, lucernas, monedas, bronces y mosaicos ${ }^{5}$. En Hispania es frecuente la representación de las distintas fases del mito de Europa sobre todo en mosaicos, y en menor medida en escultura de terracota y bronce, cerámica, monedas y gemas, tal vez como consecuencia de la interpretatio romana del anterior culto a Astarté ${ }^{6}$. El momento inmediato del rapto ha quedado plasmado en los mosaicos de Itálica y de Fernán Núñez; el comienzo de la travesia marina se documenta en el mosaico de Mérida, en lucerna de Menorca, en entalles de lbiza y de Andújar y en un bronce tardío que, procedente de Mérida, formó parte de las colecciones del Museo Lázaro Galdiano de Madrid; el viaje marino propiamente dicho se ha representado en dos pavimentos de Ecija, en lucernas de Mérida, Conímbriga, Bílbilis, Caesaragusta y Pollentia, sigillata de Andújar, terracota de Sisapo y en moneda de Cástulo. La hierogamia, como alegoría de la estación primaveral, es recordada en el mosaico de Córdoba.

La primera fase de la leyenda que narra los preliminares del rapto (Mosch. II 30-99; Ovid. Met. II 875), fué la preferida por los artistas de época helenística que la plasmaron en numerosos vasos apulios. De esta etapa hay distintas versiones iconográficas, siendo la más simplificada la que muestra a Europa en pie, cogiendo flores en un cesto, tal como la describe Moschos (II 34, 37-62) y se encuentra documentada en una pintura de Stabiae, de mediados del siglo I d.C. ${ }^{7}$, y en monedas de Tyro, de mediados del siglo III d.C., donde Europa aparece como "sacerdotisa de las rocas ambrosías", es decir de los dos bloques errantes que, según el testimonio de Nonnos (Dion. XL 465-500), que data del siglo $V$ d.C., fueron fijados en medio de las olas bajo las indicaciones de Melkart-Herakles y sirvieron de fundación a la ciudad (Fig. 1). Con ligeras variantes, se muestra a Europa de frente, en pie, vestida con largo chiton y velo a franjas que

5 E. ZAHN, Europa und der Stier, Würzburg 1983, passim; LIMC IV/2, 32-48; G. LóPEZ Monteagudo, M.P. San Nicolás Pedraz, La iconografia del Rapto de Europa en el Mediterráneo occidental. A propósito de una lucerna del Museo de Sassari, L'Africa romana VIII, Sassari 1991, 1005-1018; O. WATTEL-DE CROIZANT, Les mosaiques representant le mythe d'Europe (ler-Vle sié. cles. Evolution el interprétation des modèles grecs en milieu romain, París 1995, donde se recoge toda la bibliografía anterior, por lo que en las citas bibliográficas de los mosaicos solamente se hace referencia a este libro, citado en adelante WATTEL, 1995.

6 G. López Monteagudo-M.P. SAn Nicolás Pedraz, Astarté-Europa en la Península lbérica. Un ejemplo de interpretatio romana, Homen. M. Fernández-Miranda (en prensa), con el catálogo de las representaciones hispanas del mito de Europa.

7 K. SCHEFOLd, La peinture pompeïanne. Essai sur l'évolution de sa signification, Bruxelles $1972,165 \cdot 166, \mathrm{pl}$. XXX. 


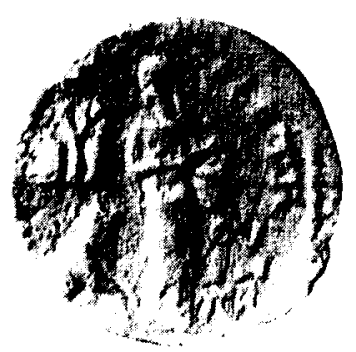

Figura 1. Moneda de Tyro.

desciende hasta las rodillas; dobla la mano derecha sobre el pecho, mientras que con la izquierda sostiene un vaso o cesto; debajo o a un lado se levantan las dos estelas junto al olivo sagrado y el agua fecundante tan venerada en todo el Próximo Oriente; en el borde a la derecha, el murex del que se obtiene la púrpura; detrás de Europa o en la parte de abajo se ha representado un toro con giba saliendo de las aguas, tal vez haciendo alusión al citado relato de Johannes Malala (Chron. II 34) donde se dice que Tyro fué asaltada por Tauros, rey de Creta, que surgió del mar por sorpresa e hizo prisionera a la princesa (vid. supra); la escena se acompaña de las incripciones en griego EV/RO/PE, EVRO/PE PE/TRE A/MBROSIE o EVRO/PE IE/RIA A/MBRO/SION/PET/RON («Europa, sacerdotisa de las Rocas Ambrosias") ${ }^{8}$. Estas monedas revelan, por una parte, la condición de sacerdotisa de Europa antes de su rapto por Zeus y, por otra, constituyen un testimonio patente del antagonismo existente desde siempre entre Tyro y Sidón, ya que con ellas Tyro intenta acaparar para gloria de sus orígenes y de sus cultos el mito de Europa, localizado por Nonnos (Dion. I 46 ss.) en Sidón, ciudad que desde su autonomía en el año 174 a.C. había utilizado sin cesar el rapto de Europa como tipo de reverso en sus monedas. Los habitantes de Tyro bajo Valeriano hacen de Europa la "sacerdotisa de las rocas ambrosías", la sirviente de los dos bloques que sirvieron de fundamento a la ciudad (Nonnos, Dion. XL 467

\footnotetext{
B E. BABELon, Les Perses achéménides, les satrapes et les dynastes tributaires de leur empire. Cypre et Phénice, París 1893, $n^{\circ} 2348 ;$ J. Rouvier, Numismatique des villes de la Phénicie. Tyr, JIAN 7, 1904, 65 ss. $n^{\circ} 2471,2507,2541$; G.F. HILL, BMC, Phoenicia, London 1910, 290, $\mathrm{n}^{\circ}$ 468, pl.. XXXIV, 13; R. MOUTERDE, Europe, prêtresse des roches ambrosiennes, MUSJ 25, 194243, 77-79, fig. 10; B. Servals-Soyez, Les monnaies impériales de Tyr, St. Phoen. I-II, 1983, 100103; P. Naster, Ambrosiai Petrai dans les textes et sur les monnaies de Tyr, St. Phoen. IV, 1986 361-371. R. DU MESNIL Du BuISSON, L'ancien dieu tyrien Ousô sur des monnaies de Tyr, MUSJ 41, 1965,15 , propone la lectura «ieron", es decir sacrum, referido al olivo sagrado de las "piedras ambrosias", en lugar de "iereia" o sacerdotisa, apelativo que no parece corresponder, según este autor, a una diosa.
} 
ss.), donde existía un templo dedicado a la diosa, según el testimonio de Flavio Josefo (contra Apion 1 118).

Las versiones en mosaico, que siguen los modelos de los vasos griegos de figuras rojas procedentes del Sur de Italia ${ }^{9}$, muestran al toro de pie o sentado y con la cabeza agachada en señal de sumisión, recordando el relato de Nonnos (Dion. 1 50-52): «El (el toro) se posternó y bajó la encorvada cerviz, para que lo monte la muchacha», mientras que Europa aparece, más o menos desnuda, en pie o ya sentada sobre el toro, en posición frontal o de espaldas, sola o junto a sus compañeras, adornando al animal con guirnaldas de flores, mientras que estas últimas le ofrecen comida: mosaicos de Keynsham, del siglo IV d.C., en el que el toro aparece sentado apaciblemente y montado por Europa que, de forma confiada, le adorna con una guirnada, mientras su compañera le ofrece un cesto de comida (Fig. 2); de Oudna, del III d.C., donde Europa, sentada de espaldas sobre un toro de pequeño tamaño y actitud sumisa, sostiene en la mano izquierda una guirnalda de flores evocando los versos de Ovidio

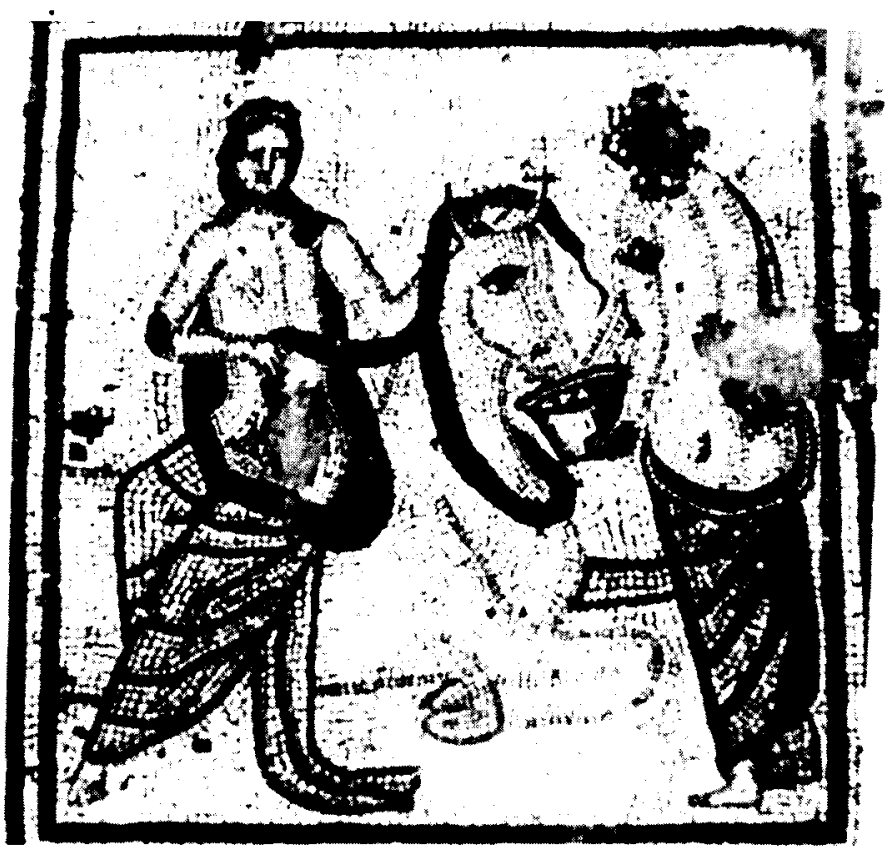

Figura 2. Mosaico de Keynsham. Villa romana.

9 Cf. LIMC IV, «Europe I», n 4-11. 
(Met. II 869-871), mientras sus compañeras, una en pie y la otra arrodillada, le ofrecen comida; la presencia del eros y la desnudez de los personajes proporcionan a la escena el contenido erótico que va a caracterizar el resto del relato mítico (Fig. 3); y de Ouled Agla, datado en el siglo IV d.C., en el que se muestra a la princesa sidonia en pie, poniendo una guirnalda de flores rosas alrededor del cuello del toro. ${ }^{10}$.

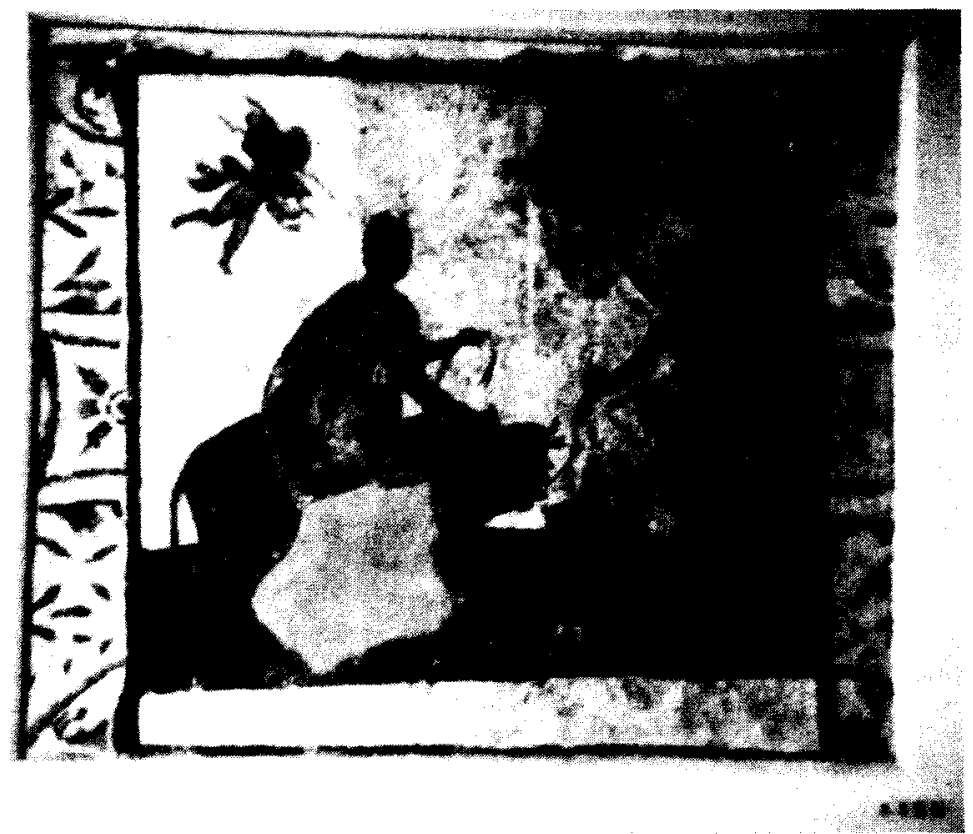

Figura 3. Mosaico de Oudna. Museo de El Bardo. (Foto G. López Monteagudo).

El tipo iconográfico de Europa sentada de espaldas, como aparece en el pavimento de Oudna y se documenta también en los mosaicos de Palestrina y de Cannes, fechados en los siglos I y II d.C., y el de nereida o Europa en el de Henchir Thina, del siglo III o IV d.C., que figuran ya la tercera fase del mito, destacando en todos ellos la ostentosa desnudez de la princesa cubierta solo en parte por el himation, al parecer está inspirado en una pintura helenística de Apeles ya, que según Plinio ( $N H$ XXXV 79; 94 ), este pintor se distinguía por "la gracia" de su arte y por sus «personajes vistos de espaldas", que debía figurar junto a otros cuadros traídos

10 WATTEL, $1995,194-195,214-220$, pl. XXIV-a, XXVIII y XXIX. 
de Alejandría por Octavio hacia el 30 a.C., como el de Cadmos y Europa de Antifiles (ca. 300 a.C.), que decoraba el pórtico de Pompeyo en Roma (Plin. NH XXXV 114), o las escenas del Rapto de Europa expuestas en el templo del divino Augusto y en el pórtico de Europa en el campo de Marte (Mart. epigr. XIV 180; II 14) ${ }^{11}$.

Idéntico tipo iconográfico se ha utilizado para representar a algunas ménades en lucernas romanas, como se ve en una lucerna de Vic decorada con un grupo dionisiaco formado por una ménade, cuya desnudez cubre sólo en parte con el strophonion y el himation, sentada de espaldas sobre el asno conducido por Sileno ${ }^{12}$ (Fig. 4). La similitud iconográfica entre esta

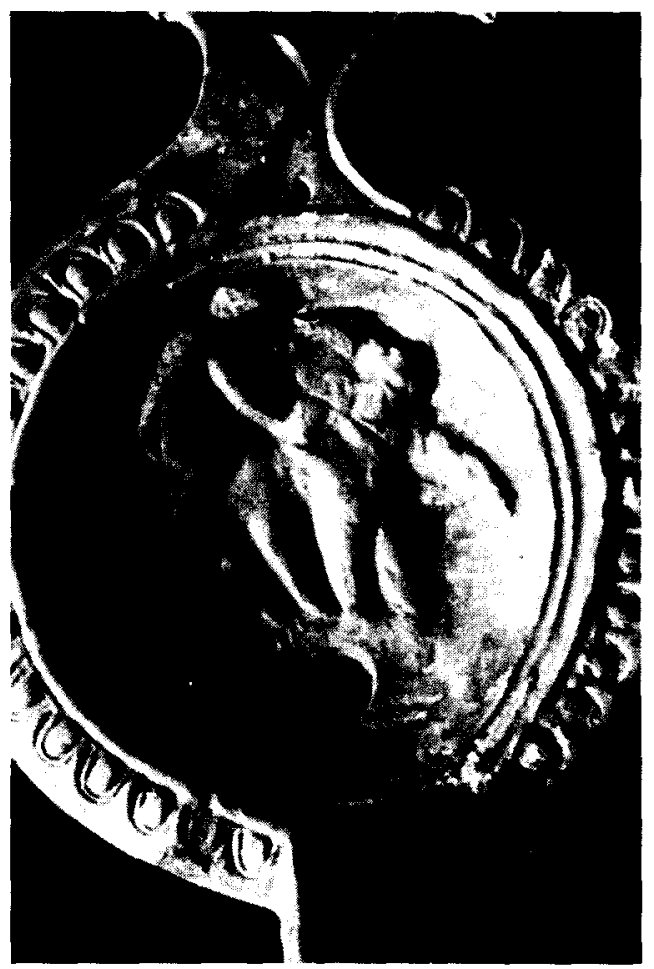

Figura 4. Lucerna de Vic. Museo Episcopal de Vic. (Foto G. López Monteagudo).

11 WATTEL, 1995, 38-41, 73-92, 214-217, 221-224, pl. VII, VIIIa, XXVIII y XXIX b.

12 Ejemplar inédito conservado en el Museo Episcopal de Vic. Agradecemos a D. Miquel S. Gros Pujol las facilidades dadas para su estudio y fotografia que ahora se publica. La misma escena se documenta en lucerna de Vindonissa, cf. S. Loeschcke, Lampen aus Vindonissa, Zürich $1919, n^{\circ} 26$, Taf. $\vee 26$, con todos los paralelos. 
escena y las representadas en los mosaicos citados, en especial el de Oudna, donde Europa también lleva strophonion, indica la existencia de un modelo común para ambas escenas, así como la contaminación del mito de Europa con el ciclo dionisiaco. Al fin y al cabo en la literatura mistérica Europa es considerada frecuentemente como una bacante, una mystis de los ritos dionisiacos y como una alegoría del alma que avanza por la "vía de Zeus», por la vía de la salvación del hiéro gamos ${ }^{13}$.

Un segundo momento dentro de los preliminares del rapto e inmediatamente anterior al mismo muestran a Europa caminando junto al toro que, de forma reposada, inicia la marcha hacia el mar, como se ve en un crátera de figuras rojas, de ca. 480 a.C., procedente de Tarquinia y conservado en el MAN de Madrid ${ }^{14}$ (Fig. 5), o en una terracota del siglo II de la Antike Sammlung de Münich ${ }^{15}$ (Fig. 6). Hispania ha dado

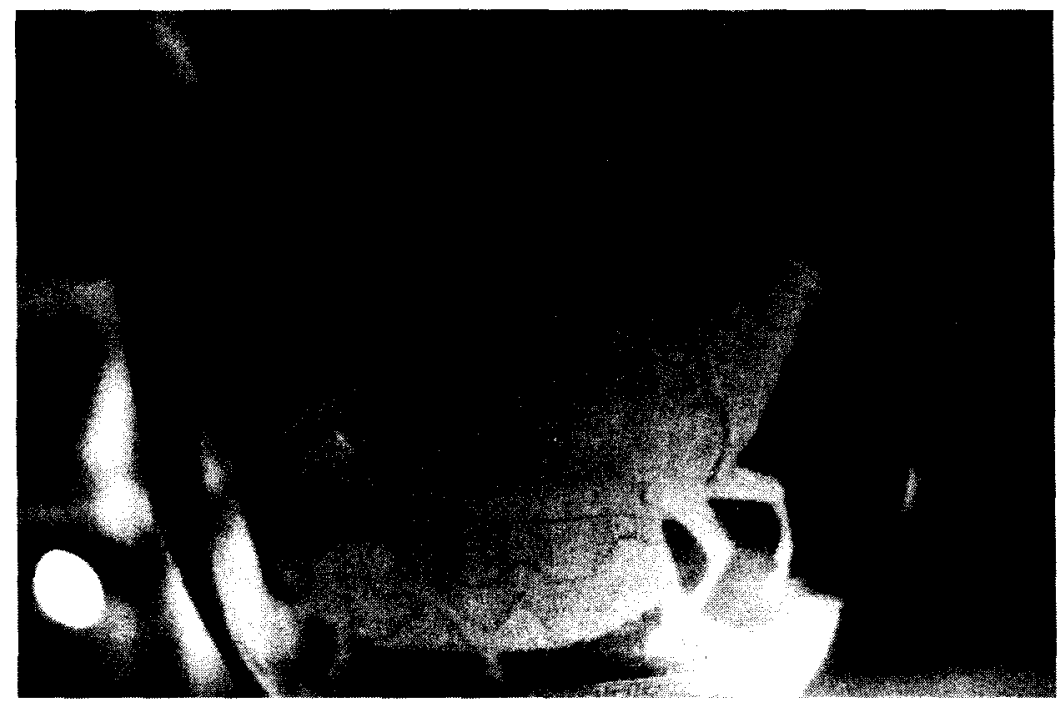

Figura 5. Crátera de Tarquinia. MAN de Madrid. (Foto G. López Monteagudo).

un ejemplo musivo de esta secuencia en el pavimento de ltálica (Sevilla) con la representación de los Amores de Júpiter, que se conserva en la colección de la Condesa de Lebrija, y se data en la segun-

13 D. LEVI, Mors voluntaria, Mystery Cults on Mosaics from Antioch, Berytus VII, 1942, 44.

14 Ejemplar idéntico en LIMC IV, «Europe l», n².

15 № 205, Col. Hans von Schoen. 


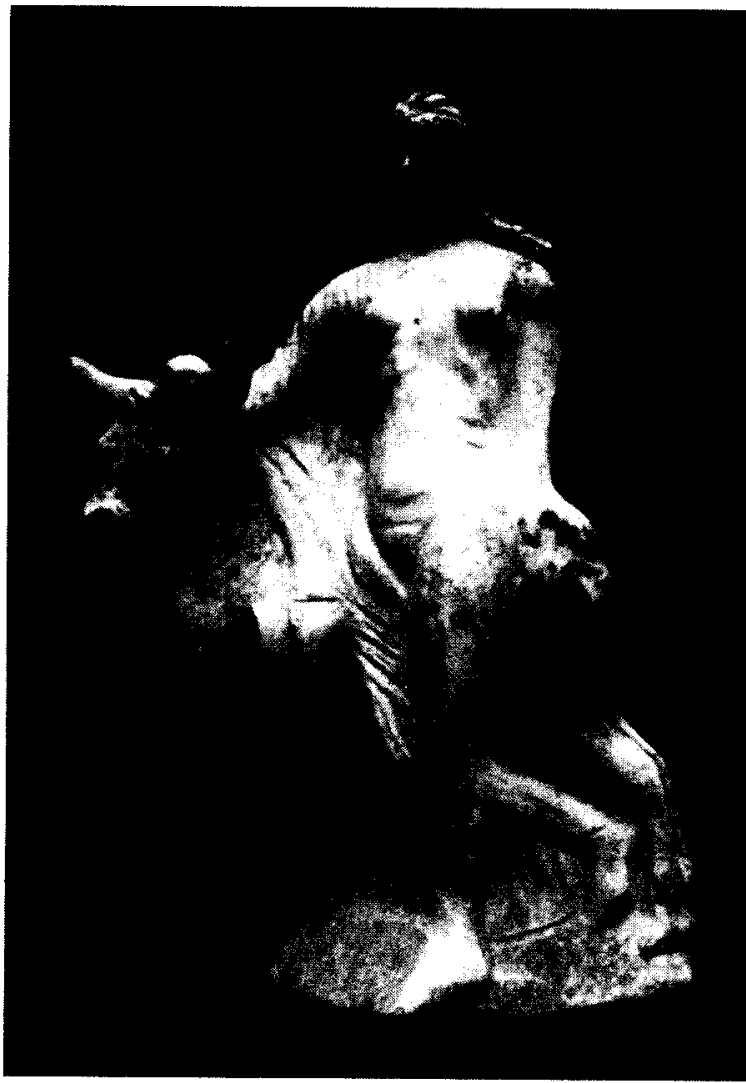

Figura 6. Terracota. Antike Samlung de Munich. (Foto G. López MonteAGudo).

da mitad del siglo II d.C. ${ }^{16}$ (Fig. 7). La superficie del pavimento, que forma prácticamente un cuadrado de $6,85 \mathrm{~m}$. de lado, ostenta un esquema compositivo de cuadriculado de círculos grandes y pequeños tangentes, nueve grandes y ocho pequeños, en lacería de trenza de dos cabos, que determinan cuatro octógonos irregulares cóncavos ${ }^{17}$. En Hispania el mismo esquema compositivo se documenta en otro mo-

16 CMRE II, 1978, 25-26, nº 1, láms. 1 y 3b.

17 C. BALMELLE ET ALII, Le décor géométrique de la mosaïque romaine, París 1985, pl. 236 bc. Este tipo de composición pertenece al grupo denominado por Salies "Kreissystem IV b", documentándose en una amplia zona geográfica con una cronología que va de comienzos del s. II hasta los inicios del VI d.C., cf. G. SALIES, "Untersuchungen zu den geometrischen Gliederungschemata römischer Mosaiken", $B J b$ 174, 1974, 16, 165-167. 
saico italicense, el de Galatea, datado a fines del siglo III d.C., y en el pavimento báquico de El Ejido (Almeria), de fecha algo anterior ${ }^{18}$. El medallón central se ha decorado con un busto masculino tocando la siringa, identificado probablemente con Argos y también con Pan, Apolo o Polifemo, mientras que las Estaciones ocupan los cuatro medallones de los ángulos. Los cuatro rondos restantes, situados en el centro de los lados, van ocupados por escenas mitológicas sacadas del ciclo de los amores de Júpiter: Leda y el cisne, Ganímedes ofreciendo el contenido de una pátera al águila de Zeus, Dánae recibiendo la lluvia de oro y finalmente la vaca lo con la media luna marcada en su vientre. Los octógonos centrales ofrecen otros temas del repertorio de los Amores de Júpiter: Europa y el toro, Arcas y Calisto metamorfoseada en osa, sátiro persiguiendo a Antiope; el cuarto va decorado con la imagen alegórica del río Asopos, cuya hija Egina fué raptada por Zeus.

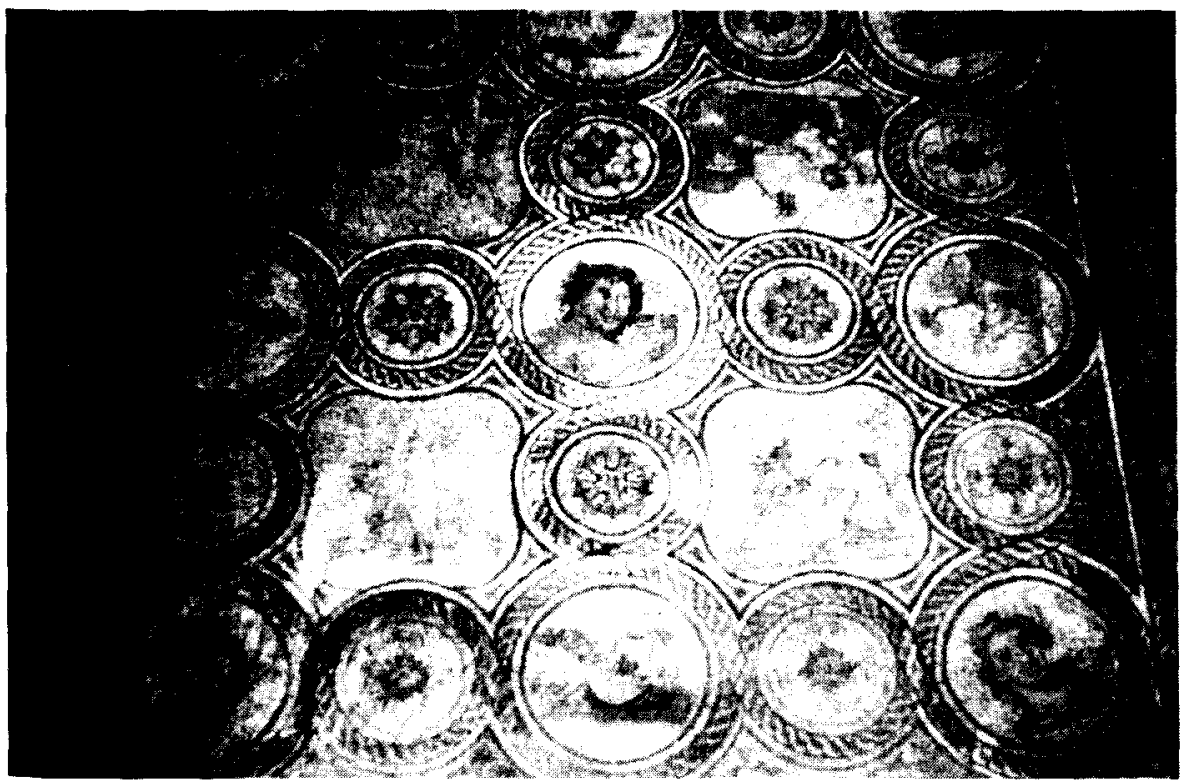

Figura 7. Itálica. Mosaico de los Amores de Júpiter. Casa de la Condesa de Lebrija.

18 CMRE II, 1978, n 42, lám. 77, A. SUÁREZ ET ALIl, “Memoria de la excavación de urgencia realizada en el yacimiento de Ciavieja (El Ejido, Almería), 1985", Anuario Arqueológico de Andalucia III. Actividades de Urgencia, 1985 (1987), 14 ss. 
El grupo formado por Europa y el toro se ha situado en la orilla del mar en marcha hacia la izquierda (Fig. 8). La princesa sidonia camina desnuda al lado del toro, con la pierna derecha avanzada y la izquierda ligeramente flexionada; está vista de frente, en posición de tres cuartos, agarrando con la mano derecha el cuerno del toro, mientras que con la izquierda levanta por detrás del hombro de este lado el manto de color rojo, que le cae por la espalda y se enrolla en la pierna derecha; tiene la cabeza vuelta hacia atrás, como si mirara a sus compañeras ausentes - en el cuadro. El mosaista ha representado el momento de transición inmediato al rapto, en el que la joven ya ha sido seducida por el animal e inicia la marcha hacia el agua, aunque aún no se ha sentado sobre su grupa.

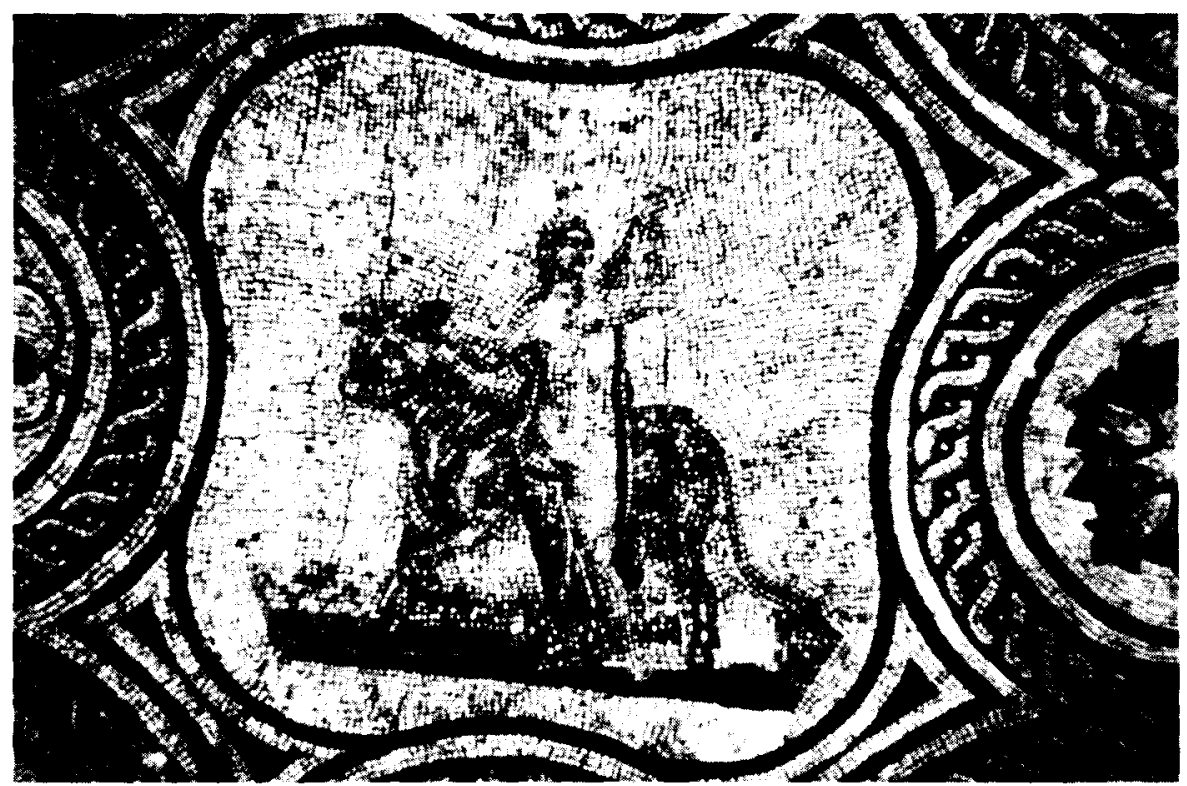

Figura 8. Itálica. Mosaico de los Amores de Júpiter. Casa de la Condesa de Lebrija.

El tipo iconográfico de Europa de pie junto al toro, dentro del repertorio mitológico de los amores de Júpiter, se vuelve a encontrar en los mosaicos de Ouled Agla, Palermo y Halicarnaso, datados a lo largo del siglo IV d.C. El mosaico argelino de Ouled-Agla (Equizitum), que se fecha a comiezos del siglo, ostenta una interesante composición rectangular, en cuyo emblema figura, entre otros "Amores de Júpiter", Europa adornando con una guirnalda de flores rosas el cuello del toro, que vuelve la cabeza hacia la princesa con un gesto de seducción 


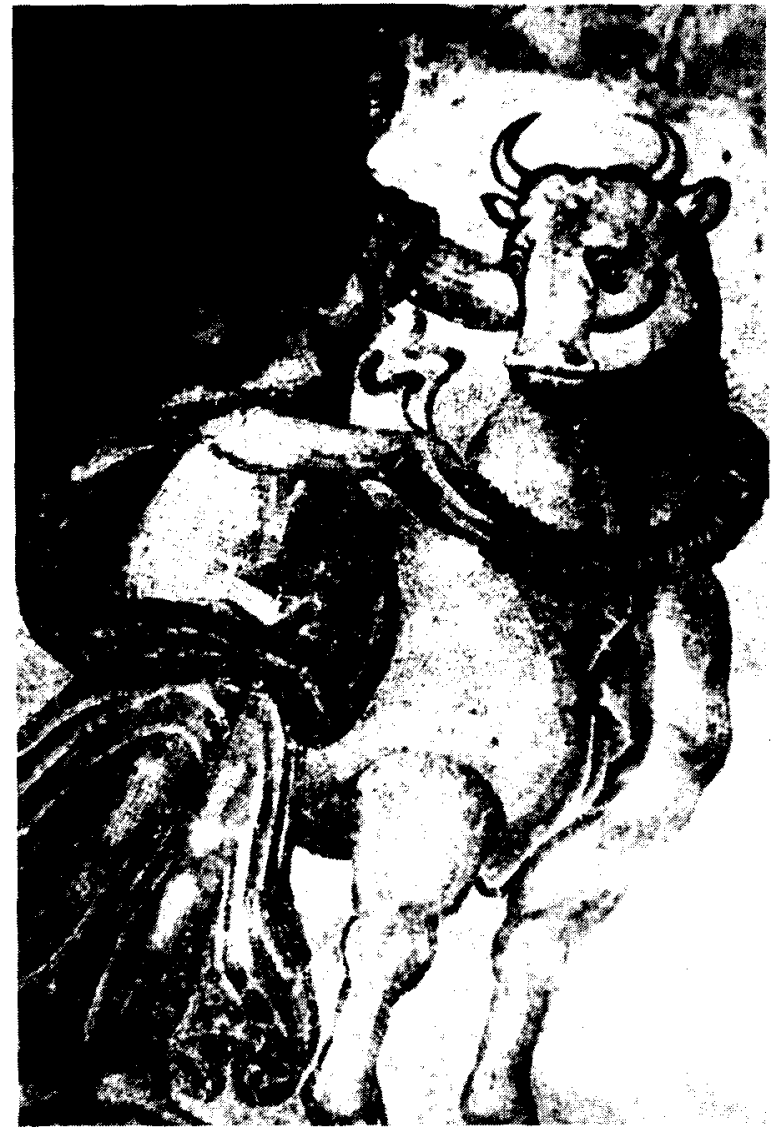

Figura 9. Mosaico de Ouled Agla. Museo Nacional de Argel.

amorosa ${ }^{19}$ (Fig. 9). En el pavimento de Palermo, que al parecer decoraba una capilla privada destinada a cultos mistéricos dionisiacos, el grupo formado por Europa y el toro se destacaba del resto de los cuadros decorados con los "Amores de Júpiter", dispuestos en la zona terrestre, ocupando un lugar privilegiado en el Olimpo dentro del thiasos marino ${ }^{20}$. En el ejemplar más tardío de Halicarnaso, puesto que se fecha ya a finales del siglo IV, se ha representado a la pareja divina

19 WATTEL, 1995, 217-219, pl. XXIX-a. Una imagen basante semejante debió representarse en el perdido mosaico de EI Djem, cf. IBID., 220-221.

20 R. Camerato-Scovazzo, Nuove proposte sul grande mosaico di Piazza della Vittoria a Palermo, Kokalos 21, 1975, 231 ss; WATEL, 1995, 126-127, pl. XIV-b. 
caminando hacia la derecha delante de un árbol que indica el paisaje terrestre. Europa lleva una túnica de color azul que, echada sobre el hombro izquierdo, cae sobre las piernas dejando al descubierto el cuerpo, y adorna su cabeza con una corona vegetal. No hay en esta figura la sensación de movimiento que se adivina en las patas del animal, el cual aparece con la cabeza vuelta hacia la jóven ${ }^{21}$.

La Península Ibérica ha dado otro documento arqueológico de los preliminares inmediatos al rapto, aunque de fecha muy anterior, paralelizable en algunos detalles a la escena representada en el mosaico de Itálica. El grupo representado en un escarabeo "greco-fenicio" de jaspe verde, de la primera mitad del siglo $\mathrm{V}$ a.C., que procedente de lbiza se conserva en el Museo Arqueológico Nacional (Fig. 10), muestra a Europa vestida con chiton ya sentada de perfil sobre el toro, al que agarra con su mano derecha por el cuerno; el animal camina tranquilamente por el agua, como indica la línea en forma de $V$ invertida figurada entre sus patas, con la cabeza vuelta hacia la princesa, quien a su vez también vuelve la cabeza para atrás como mirando a sus compañeras, ausentes del cuadro, al igual que ocurre en el mosaico italicense ${ }^{22}$. El tipo se repite en cerámica griega de fines del siglo VI y comienzos del V a.C., baste recordar el plato griego procedente

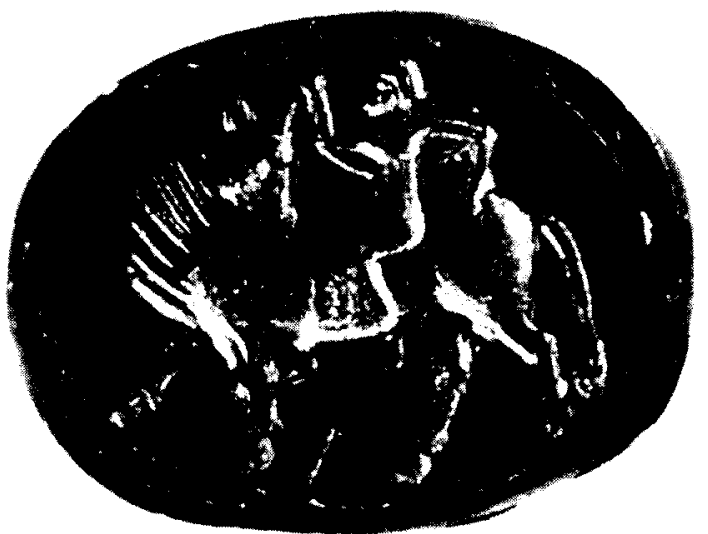

Figura 10. Escarabeo de Ibiza. MAN de Madrid.

21 WATTEL, 1995, 207-209, pl. XXVII.

22 MAN, No 36994. A. VIVEs y ESCUDERo, Estudios de Arqueología Cartaginesa. Necrópolis de Ibiza, Madrid 1917, n 353, lám. XXV, 9; J. BOARDMAN, Greek Myths on "Greco-Phoenician" Scarabs, Festschr. U. Hausmann, 1982, 297, pl. 66, 7; ID, Escarabeos de piedra procedentes de Ibiza, Madrid 1984, lám. XXXV, 217. 
de Egina, de ca. 470 a.C., que se conserva en la Antike Sammlung de Munich (Fig. 11), o la pelike del Pintor de Boston, fechada en el 460 a.C., que se guarda en el Albertinum de Dresde ${ }^{23}$ (Fig. 12).

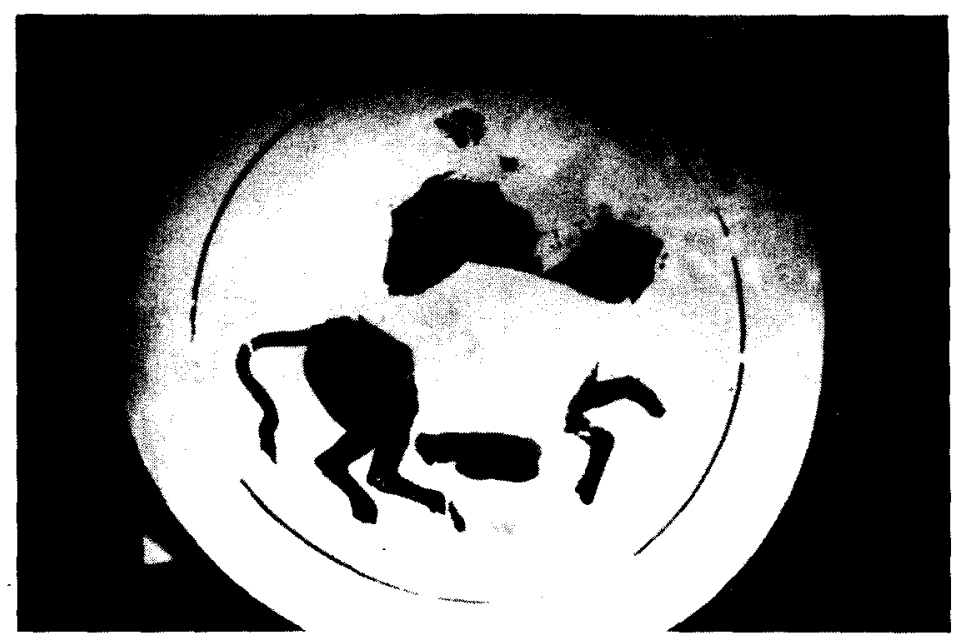

Figura 11. Plato de Egina. Antike Sammlung de Munich. (Foto G. LOPEZ MONTEAGUDO).

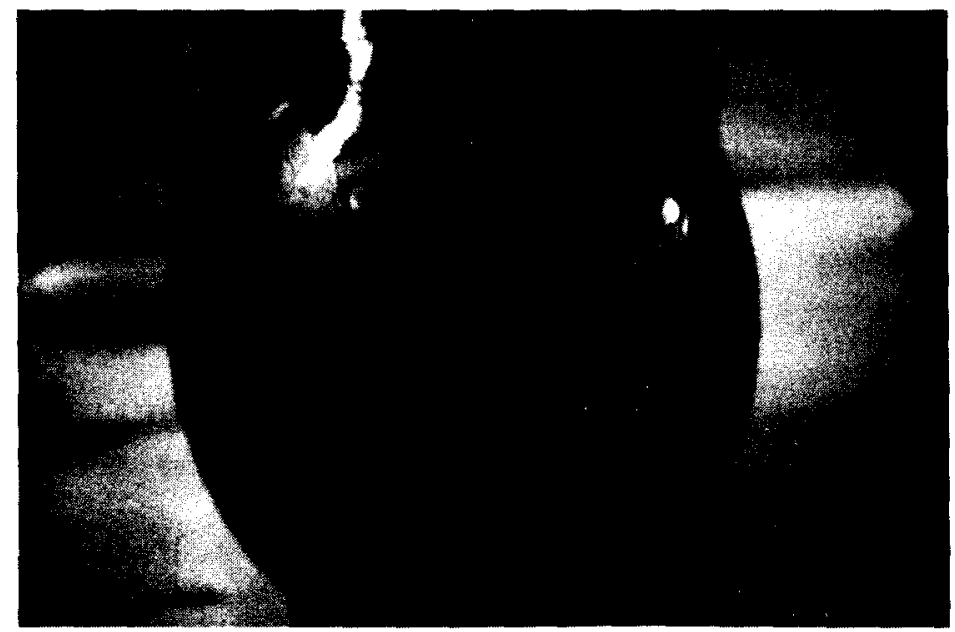

Figura 12. Pelike del Pintor de Boston. Albertinum de Dresde. (Foto G. LOPEZ MONTEAGUDO).

23 Cf. LIMC IV, «Europe l», $n^{9} 27,36,42,44,46,51,52$ y 55. 
El mismo tipo iconográfico de Europa montada sobre el toro, vestida con peplos y sin velo arqueado sobre la cabeza se atestigua en obras fechadas del 550 al 450 a.C., como las terracotas beocias de ca. 500 a.C. (Figs. 13-14), monedas de Cyzicus, Marion o Gortyna (Fig. 15), del siglo V

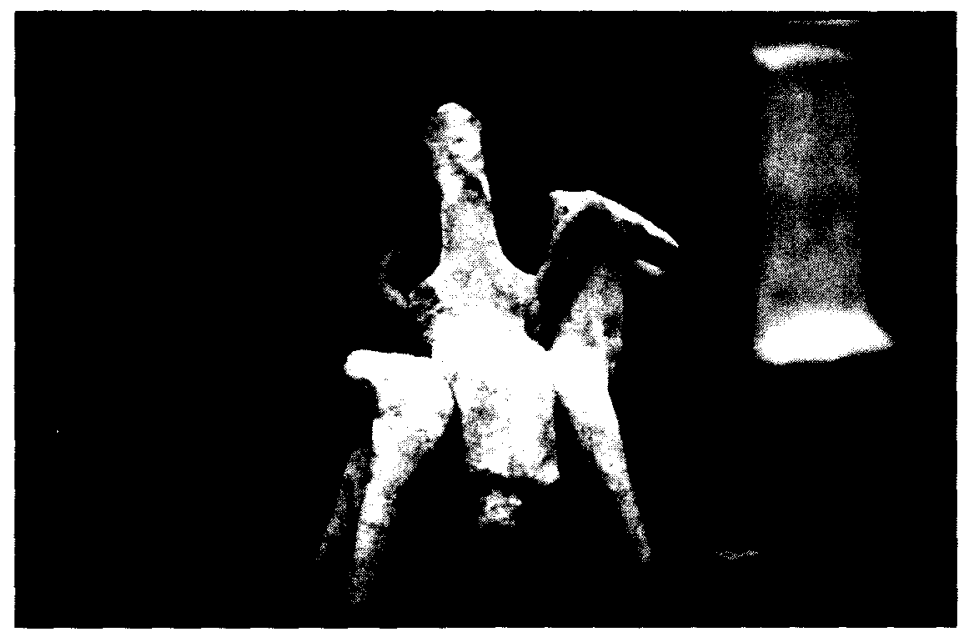

Figura 13. Terracota beocia. Antike Sammlung de Munich. (Foto G. LÓPEZ MONTEAGUDO).

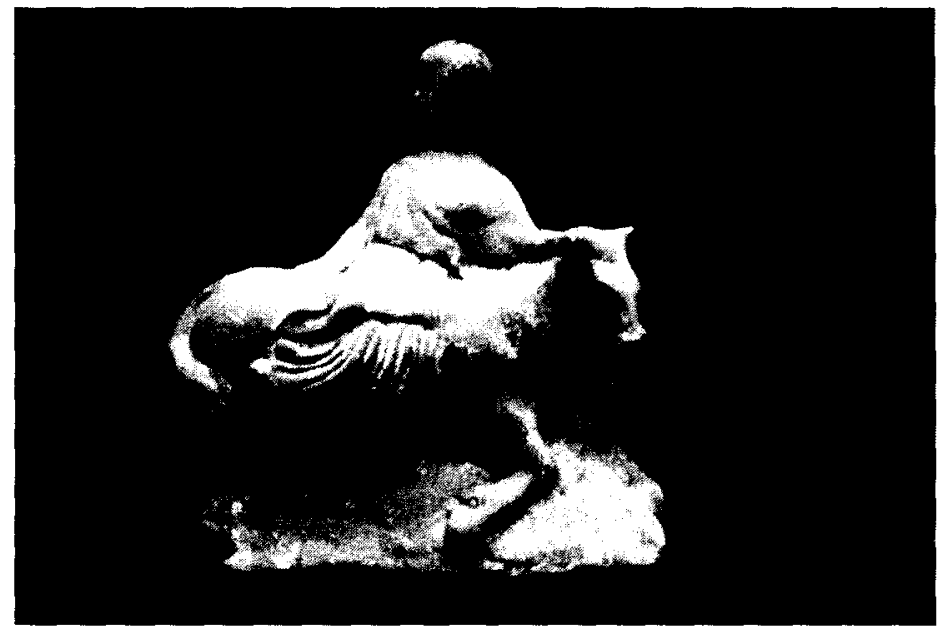

Figura 14. Terracota beocia. Antike Sammlung de Munich. (Foto G. LópEZ MONTEAGUDO). 


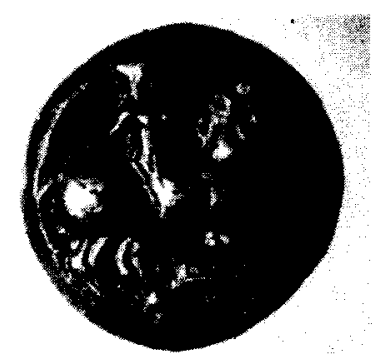

Figura 15. Moneda de Gortyna.

a.C., entalles del siglo $V$ al IV-III a.C. ${ }^{24}$ y quizás en lucerna romana de Pollentia (Mallorca) ${ }^{25}$ (Fig. 16, 1). El prototipo iconográfico de una divinidad masculina o femenina montada sobre el dorso de un toro se documenta ya en Anatolia a finales del segundo milenio, de donde se difunde ampliamente por Siria, Fenicia y Mesopotamia ${ }^{26}$. En el arte griego arcaico el modelo iconográfico remonta a fines del siglo VIl o a comienzos del VI a.C., documentándose en las metopas de Delfos y Selinunte ${ }^{27}$. No hay, sin embargo, en estos primeros documentos plásticos ninguna relación con el Oriente ni con la diosa Astarté, ya que Europa viste chiton de tipo dorio y lleva el himation enrollado en el brazo izquierdo y no inflado sobre la cabeza.

La segunda fase del mito, que es el momento mismo del rapto, ofrece algunas variantes iconográficas. En una de ellas el toro inicia la marcha hacia el mar con dulzura, evocando los versos de Ovidio (Met. II 869-871) y de Nonnos (Dion. I 52-53), con objeto de mantener la confianza de Europa durante más tiempo, o de forma violenta, siguiendo la versión de Moschos (II 110). En todos los casos la transición se efectúa ante el asombro de las compañeras de la princesa sidonia, a la que se representa vestida o semidesnuda e iniciando el gesto de levantar el manto o el extremo del himation por detrás de la espalda, aunque en ocasiones éste

24 LIMC IV, “Europe I», $\mathrm{n}^{\mathrm{Q}}$ 114-116; 105-107; 82-87. El tipo iconográfico de diosa montada sobre el toro se utiliza también en las representaciones tempranas de Afrodita, cf. LIMC II, "Aphrodite", IVE.

25 M.L. Palanques, Las lucernas de Pollentina, Palma de Mallorca 1992, 56-57, $n^{\circ} 706$, fig. 14, lám. XXVII. Pieza muy desgastada procedente de la tumba $n^{\circ} 19$ de Ca'n Fanals, con la representación de una figura femenina, vestida con larga túnica, montada sobre un animal cuadrúedo. A pesar de que la mujer no lleva el típico velo inflado sobre su cabeza, como es habitual, M.L. Palenques cree indentificar en este grupo una representación del rapto de Europa.

26 J. BABELON, Le voile d'Europe, RA XX, 1943, 126-127, pl. I; EAA III, 542.

27 LIMC IV, “Europe I", no 77-81. 
aparece ya arqueado sobre la cabeza como insuflado por el viento que provoca el rápido salto del toro hacia el agua. Ejemplos de esta etapa de la leyenda serían las pinturas romanas de la Casa Dorada y de la tumba de los Nasonii ${ }^{28}$.
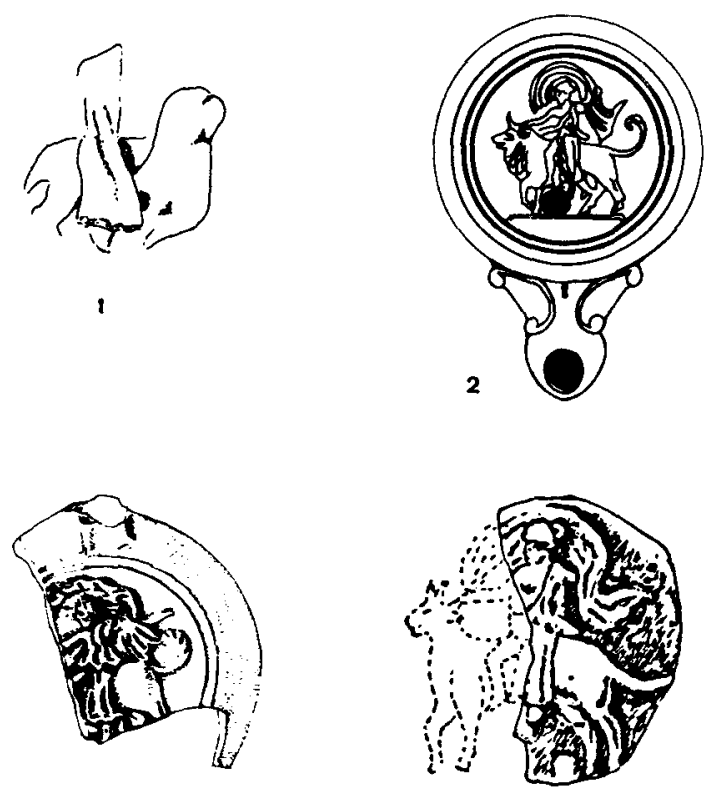

3

4
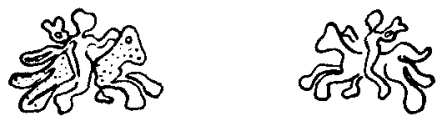

5

Figura 16. 1. Lucerna de Pollentia (Mallorca). 2. Lucerna de Ciudadela (Menorca). 3. Lucerna de Conimbriga (Coimbra). 4. Lucerna de Bilbilis (Calatayud). 5. Sigillata de Andújar (Jaén).

Los documentos arqueológicos hispanos de esta fase del mito ofrecen la versión no violenta del rapto, siguiendo la secuencia cronológica que se había iniciado en el pavimento de Itálica. La escena inmediatamente posterior a ésta se encuentra representada en el mosaico muy destruído

S. ReinaCh, RPGR, París, $1922,12,3$ y 13,4 . 
de Fernán Núñez (Córdoba), del que se ha conservado la reproducción gráfica de algunos fragmentos, fechado a finales de la época severiana, donde el episodio del rapto de Europa por el toro se encuadra igualmente en el ciclo de los Amores de Júpiter ${ }^{29}$ (Fig. 17). Las escenas se distribuyen en nueve compartimentos, que pavimentaban una habitación de 8,23 $\times 7,46 \mathrm{~m}$., estando ocupadas las esquinas por los bustos de las cuatro estaciones, de las que solo subsisten el Otoño y el Invierno. En el cuadrado central aparece un joven nimbado, que según D. Fernández-Galiano

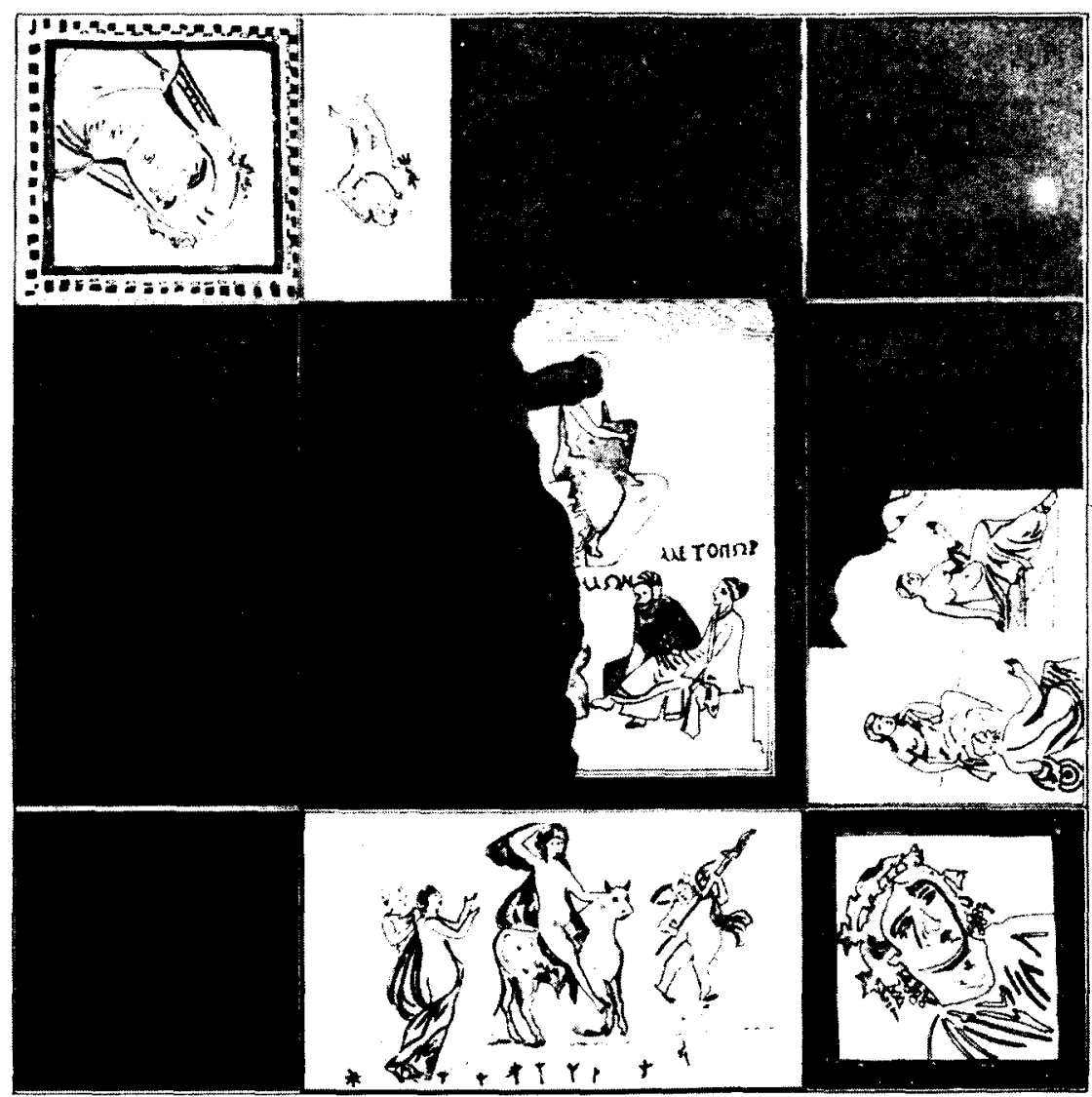

Figura 17. Mosaico de Fernán Núñez. (Según D. FERnández-Galiano).

29 CMRE III, 1981, 50-54, nº 32, lám. 32; D. FernandeZ-Galiano, Nuevas interpretaciones iconográficas sobre mosaicos hispanorromanos, Museos 1, 1982, 17 ss. 
podría ser representación de Helios/Zeus, reflejando la teología estóica de época helenística que consideraba a Helios como el equivalente de Zeus, acompañado de dos figuras alegóricas identificadas por inscripciones en griego como el Otoño y el Invierno. La comparación con el mosaico de Palermo lleva asímismo a una identificación de Helios/Dionysos, tal como se le llama en la doctrina órfica (Macr. Saturn. I 18, 18) ${ }^{30}$, donde ambos dioses se asimilan: «...Oh luminoso Zeus Dionysos, padre del mar, padre de la tierra, Sol creador de todas las cosas ..." (Mar. Saturn. 123 , 22). En los tres paneles rectangulares que subsistían en el momento de su descubrimiento, con unas medidas de 1,55 x 1,05 m., se han representado tres temas que se repiten en el mosaico de Itálica aunque tratados con distinta iconografía: el Rapto de Europa, Zeus y Antiope, Asopos y Egina.

La escena del rapto de Europa es la única que se conserva en su integridad y de la que se conoce su paradero actual, ya que se expone en el Museo Arqueológico Nacional de Madrid (Fig. 18). En ella se ha representado el momento preciso del rapto a la orilla del mar, en presencia de las compañeras de Europa que manifiestan su asombro con

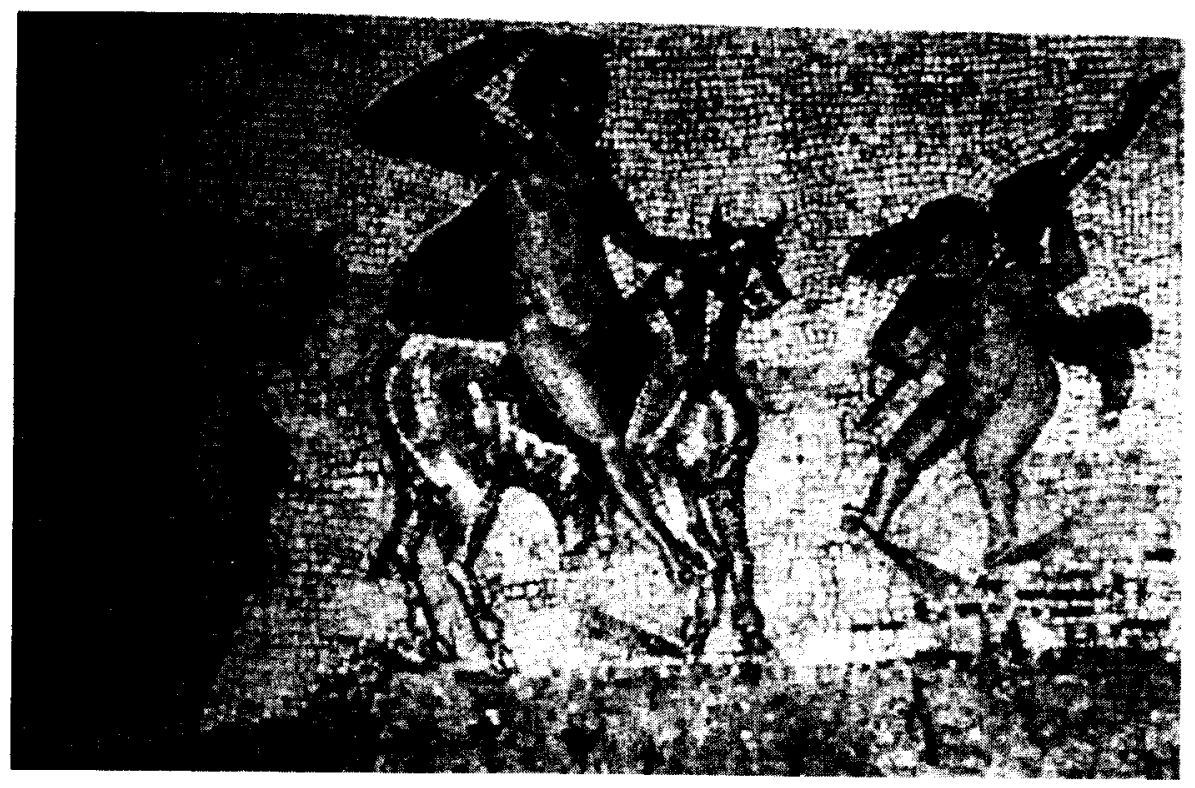

Figura 18. Mosaico de Fernán Núñez. MAN de Madrid.

30 Cf. D. LEVI, Mors voluntaria. Mystery Cults on Mosaics from Antioch, Berytus VII, 1942, 42. 
expresivos gestos. Europa aparece ya montada sobre el toro que camina tranquilamente hacia la derecha por la pradera florida, dirigiéndose al agua estimulado por Eros que flota sobre las aguas sosteniendo una antorcha, símbolo de la pasión amorosa de Zeus por Europa. La princesa está vista de tres cuartos en posición frontal, va totalmente desnuda sentada a la jineta, agarrándose con la mano izquierda al cuerno del animal, mientras que con la derecha levanta sobre la cabeza el manto de color azul que cae sobre su espalda y por el dorso del animal sirviéndole de montura, pero que aún no se arquea por encima de la cabeza. La forma de creciente lunar de los cuernos del toro es similar a la que ofrecen los mosaicos de Byblos, de la misma época que el pavimento cordobés, de Daphne, de comienzos del siglo IV d.C., y de Sarrîn, que se fecha en el VI d.C. (vid. infra), aunque en todos se

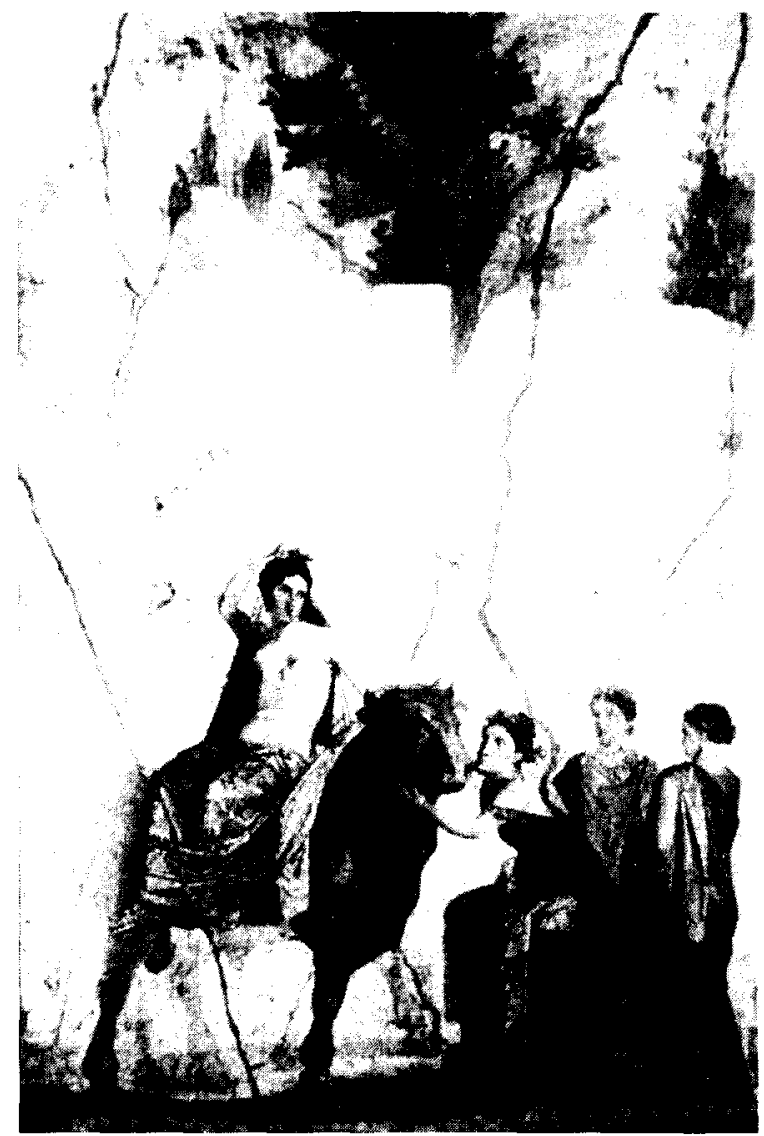

Figura 19. Pompeya. Pintura de la Casa de Jasón. Museo Nacional de Nápoles. 
representa ya la travesia marina ${ }^{31}$. Tanto este detalle como las inscripciones en griego y la representación alegórica de las Estaciones son características del Oriente, lo que denota un posible origen oriental de las fuentes de inspiración de las escenas representadas en el mosaico de Fernán Núñez. Escenas muy similares, que remontan según $\mathrm{K}$. Schefold a un prototipo de los años 330-320 a.C., como se ve en algunos vasos de figuras rojas, se representan en las pinturas pompeyanas de la Casa de Jasón (10 d.C.) y del Thermopolium (41-50 d.C.) ${ }^{32}$ (Fig. 19).

El mismo momento, es decir el inicio del rapto, parece haberse representado en una lucerna de Menorca procedente de un enterramiento de la necrópolis romana de Rafal d'Es Capità (Ciudadela), datada en la segunda mitad del siglo I d.C. ${ }^{33}$ (Fig. 16, 2); en la marca de entalle

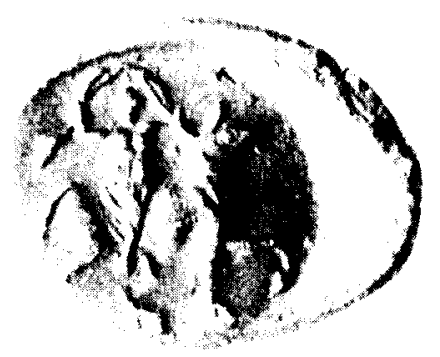

Figura 20. Marca de entalle en sigillata de Andújar.

en sigillata de Andújar (Jaén), del siglo II d.C. ${ }^{34}$ (Fig. 20); y en un bronce tardío que, procedente de Mérida, formó parte de las colecciones del Museo Lázaro Galdiano de Madrid ${ }^{35}$ (Fig. 21). En estos documentos la princesa sidonia, vestida con peplos, monta a la amazona sobre el toro que camina tranquilamente hacia la derecha sobre la línea de tierra. En la lucerna de Menorca y en el bronce de Mérida Europa se agarra con la mano izquierda al cuerno del animal, mientras que con la

WATTEL, 1995, 201-207, pl. XXV a-b y XXVIb.

32 K. SHEFOLD, La peinture pompéianne. Essai sur l'évolution de sa signification, col. Latomus 108, 1972, 240-246; LIMC IV, "Europe I", nº 56, 61, 64, 75, 125.

33 Tipo Dressel-Lamboglia 15, cf. J.C. DE Nicolas, Romanización de Menorca, Menorca 1983, 269.

${ }^{34}$ M. Sotomayor, Fondos de sigillata de Andalucia con marcas interiores de entalles, Hom. Garcia y Bellido V, Madrid 1988, 261, fig. 3: 17.

35 S. REINACH, RSGR, 1930, VI, 104, ํㅜ1; VARIOS, La colección Lázaro Galdiano de Madrid. Madrid $1927,22, n^{\circ} 482$ 
derecha sujeta el manto inflado ya sobre su cabeza. Por el contrario, en la sigillata de Andújar y también en una lucerna procedente de Mérida de los siglos I a.C.-I d.C., en la que Europa aparece sentada a la jineta sobre el toro que cabalga ya briosamente sobre el mar ${ }^{36}$, la princesa ase con las dos manos el velo que se arquea por encima de su cabeza, y es precisamente en este detalle del velo arqueado sobre la cabeza y sostenido por ambas manos en lo que más insisten los poetas latinos (Hor. Od. III 27; Ovid. Fast. V 607-610), alejándose de la otra versión de Ovidio (Met. II 858-875) y también de Nonnos (Dion. I 66-69) donde

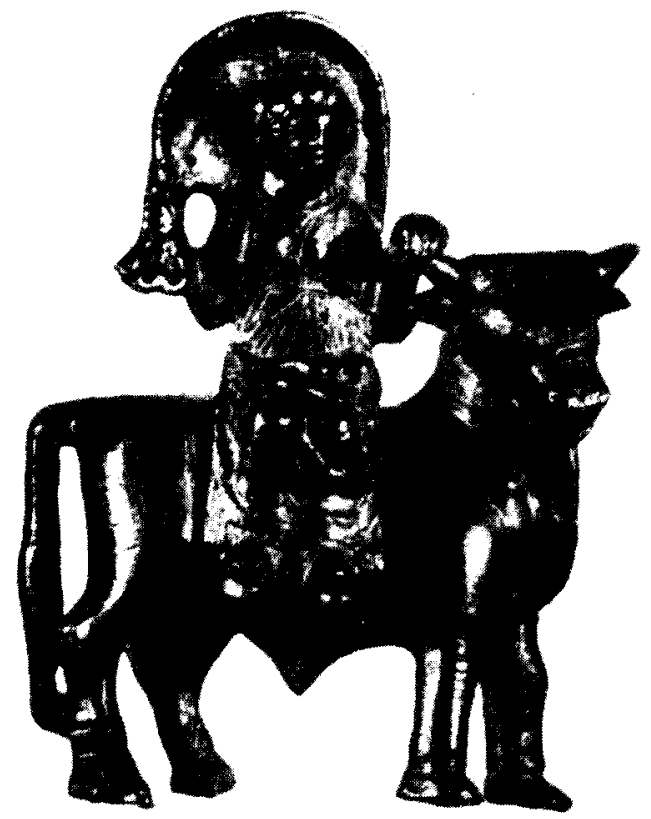

Figura 21. Bronce de Mérida. Col. Museo Lázaro Galdiano de Madrid.

Europa se agarra a los cuernos del toro. Paralelos iconográficos muy próximos se documentan en lucerna del tipo VIII B de J. Deneauve, procedente de Cartago, que se data en el el siglo II-III d.C. ${ }^{37}$ (Fig. 22), y en un espejo de bronce del Ashmolean Museum, de comienzos del siglo I

36 O. Gil. FarRes, Lucernas romanas decoradas del Museo Emeritense. Ampurias IX-X, 19471948, 102, $\mathrm{n}^{\circ}$ 1, lám. II, primera de la fila superior.

37 J. Deneauve, Lampes de Carthage, París 1969, 201, no 971, pl. LXXXVIII LIMC IV, "Europe |», 87. 
d.C. ${ }^{38}$, donde igualmente la actitud reposada del toro, que esta vez aparece caminando hacia la izquierda guiado por una antorcha, contrasta con el gesto de Europa más propio de la travesía marina, cuando ya el viento ha insuflado el velo que se arquea sobre la cabeza.

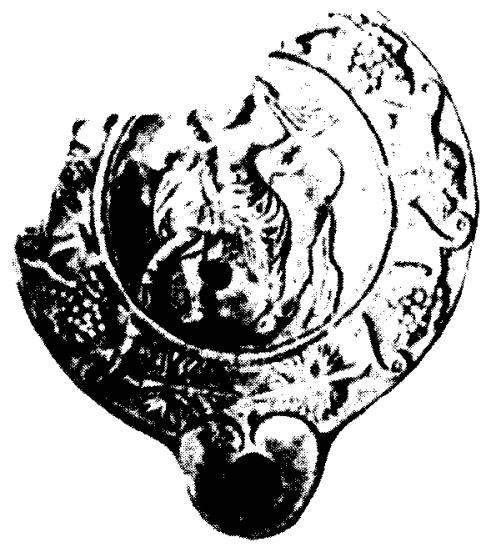

Figura 22. Lucerna de Cartago. Museo Británico.

El tipo iconográfico de Europa velificante sua manu constituye uno de los elementos más característicos del viaje marino, cuando la heroina va ya más o menos desnuda, sujetando con una mano el velo que se arquea sobre su cabeza en forma de creciente, mientras que con la otra se agarra al cuerno del toro para no caerse, evocando de esta forma los relatos de Luciano de Samosata (Dial. mar. XV) y de Moschos (II 125 ss.), o sosteniendo con ambas manos el velo arqueado sobre la cabeza, tal como se representa en la marca de sigillata de Andújar y en la lucerna de Cartago (vid. supra). El velo arqueado sobre la cabeza en forma de creciente ha sido puesto en relación con el papel de Europa como diosa lunar. Según J. Babelon representaría la bóveda celeste y Europa podría identificarse con la diosa fenicia Astarté según se deduce de Luciano de Samosata (Syr. dea. 4) que, refiriéndose al gran templo de Astarté en Sidón, relata cómo un sacerdote del lugar le habia confiado que, en realidad, el santuario estaba dedicado a Europa-Elat, siendo el toro una de las formas del dios El, que atravesó el mar junto a su paredros Asherat, suplantada en baja época por Astarté ${ }^{39}$. En el mismo tratado sobre La diosa siria, Luciano 
dice que la moneda que usaban los sidonios mostraba a Europa sentada sobre el toro-Zeus, y asi se halla documentada en ases de Sidón, de los siglos II y I a.C. y I y II d.C., donde la princesa aparece montada sobre el toro que cabalga briosamente hacia la izquierda, agarrándose con la mano izquierda al cuerno del animal, mientras que con la derecha sujeta el velo arqueado sobre su cabeza. La misma imagen, como símbolo del sincretismo entre Astarté y Europa en esos lugares, la vemos representada en monedas de época romana de Cástulo (Fig. 23), Creta, Bizancio, Hadrianopolis (Tracia) y Seleucia de Calicadnum (Cilicia) ${ }^{40}$ (vid. infra).

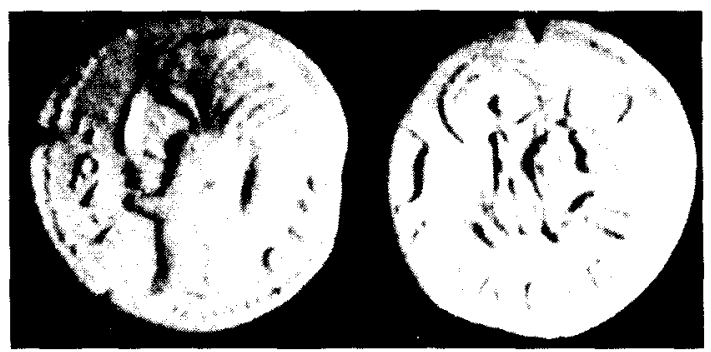

Figura 23. Moneda de Cástulo (Jaén). Col. Real de Monedas y Medallas de Copenhague.

La ecuación Europa-Astarté se halla además corroborada por el testimonio de Aquiles Tatius (I $6 \mathrm{ss}$.) que, en el siglo II d.C., describe un cuadro decorado con el rapto de Europa que colgaba en el templo de Astarté en Sidón, y así se documenta igualmente en moneda de Sidón, de Heliogábalo, de los siglos I-II d.C. En ella se ha representado la entrada del templo delimitada por dos columnas monumentales decoradas con temas vegetales, sobre las que se asienta el frontón, de forma triangular, con la figura de Astarté-Europa cabalgando el toro hacia la izquierda y con el manto arqueado sobre la cabeza, que sujeta con ambas manos; a los lados pequeñas figuras dentro de capillas, seguramente imágenes de carácter astral como ocurre en otras monedas romanas con la representación de templos dsedicados a Astarté; en el interior una estatua de Marsias, dios que acompaña a Astarté en el Oriente donde era muy venerado ${ }^{41}$.

40 LIMC IV, “Europe I», núms. 110, 201-204.

${ }^{41}$ Según se atestigua en otra moneda de Heliogábalo, de Berytus, donde se representa su imagen a la entrada de un templo coronado con altares con cuernos, y dos portadores de antorchas sobre pedestales que, según J.M. PRICE y B.L. TRELL, reforzaban el caracter astral de los cultos, como el de Sileno Marsias, cf. J.M. PrICE, B.L. TRELL, Coins and their Cities. Architecture on the ancien coins of Greece, Rome and Palestine, Londres-Michigan 1977, 150, 156, figs. 275-276 
Según J.M. Blázquez, la griega Europa puede identificarse con la semita Asherat, cuyo nombre se helenizó en Astarté o Atargatis ${ }^{42}$. $Y$ es que el mito de Europa es una leyenda fenicia conectada originariamente con el culto a Astarté, formando parte la heroína tiria de las divinidades fenicias trasplantadas al mundo helénico (Her. IV 147 y VII 91; Paus. V 25,7; Serv. ad Aen. III 88), y así lo confirma el epíteto "Phoinikogenes» que le aplica Eurípides (Cret. fr. 472). Para R.F. Willetts los hallazgos minoicos y micénicos documentados en Ugarit desde el siglo VII a.C., hacen suponer que los cadmeos eran fenicios llegados a Grecia, vía Creta, en el Minoico Medio y que por entonces se debió producir la fusión entre los cultos fenicios del dios-toro El y de la diosa-madre Asherat con el culto indígena a la diosa-madre Hellotis, nombre con el que la mayoría de los cretenses llamaban originariamente a Europa (Steph. Bizancio, en Luc. dea syr. 6) ${ }^{43}$. Los mitólogos ven en el relato del rapto un mito solar: el dios egeo del cielo, representado en forma de toro, llevaba el epíteto de Asterius, "el estrellado", asimilándose a veces con el mismo Zeus cuya leyenda estaba enriquecida con viejas contribuciones fenicias; de este simbolismo solar derivado de la identificación Zeus-Asterius (Lyk. 1301; Apoll. Bibliot. III 1,4,3; Paus. II 31,1) nace el de Europa-Astarté, documentado por las fuentes literarias, la numismática y por la arqueología ${ }^{44}$.

Este sincretismo originario del culto a Astarté-Europa, patente en el texto de la Dea syria, en los tipos monetales de Sidón, en el templo de la diosa en Sidón, y en la iconografía de Astarté-Europa como diosa alada sobre un toro, documentada en un relieve romano procedente de Egipto que se conserva en el Landesmuseum de Mainz ${ }^{45}$, así como la forma de creciente lunar que adoptan en algunos documentos los cuernos del toro evocando la simbología astral en el culto de Astarté, explicaría el éxito y la difusión del tipo iconográfico de Europa uelificans sua manu en el Norte

J.M. BlazQuez, Los templos de Lixus (Mauritania Tingitana) y su relación con los templos de ciudades semitas representados en monedas, I Congreso Internacional "El Estrecho de Gibraltar (Ceuta 1987)", Madrid 1988, 546-547.

4.3 R.F. WiLletts, Cretan Cults and Festivals, London 1962, 152 ss. Hellotis fue tambien uno de los nombres antiguos de la ciudad de Gortyna, vid. supra nota 1.

44 DAGR II, 862 ss.

45. Coleccion del Principe Johan-Georg. Las grandes diosas de las religiones semíticas en Oriente se representaron frecuentemente con alas. Tal es el caso de la diosa cananea Anat y de la babilónica Isthar. El motivo de las alas caracteriza también el arte religioso egipcio de baja época, desde donde se extiende al mundo púnico pasando a formar parte de un cierto tipo iconográfico de Tanit vinculado exclusivamente con los santuarios y con la vida de ultratumba, es decir, con una finalidad votiva y funeraria, que perdura aún en plena época romana, cf. M.E. AUBET, Algunos espectos sobre iconografia púnica: las imágenes aladas de Tanit, Homen. Garcia y Bellido, I, Madrid 1976, 61 ss. 
de Africa y en la Península Ibérica, donde existía un fuerte arraigo del culto oriental de Astarté desde la época de las colonizaciones ${ }^{46}$.

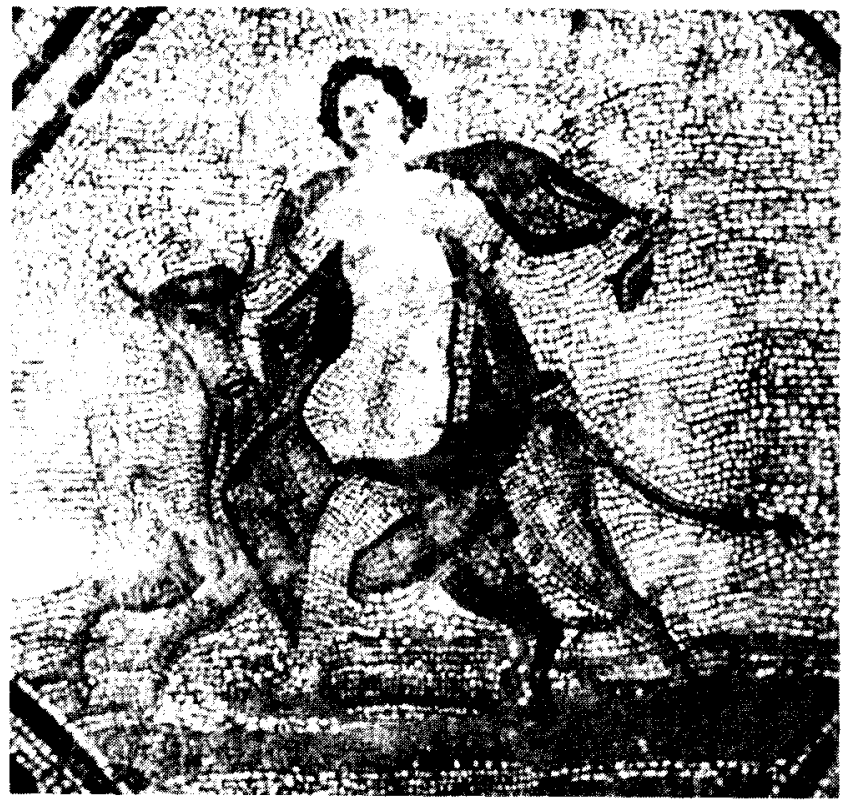

Figura 24. Mosaico de Salzburgo. Museo Carolino.

Otro recurso utilizado para figurar este momento inicial del viaje marino es el velo que se levanta por detrás de la espalda de Europa, pero que aún no se arquea sobre su cabeza, variante que se documenta en los mosaicos citados de Palestrina, Herculano y Stabiae, asi como en el de Salzburgo, datado ya a comienzos del siglo lll d.C. ${ }^{47}$ (Fig. 24). El tipo iconográfico de Europa con el velo flotando por detrás de la cabeza y no sobre ella es más antiguo en el arte griego que el del velo inflado por el viento, atestiguándose a partir de la segunda mitad del siglo V a.C., entre

46 J.M. Blázouez, Diccionario de las Religiones Prerromanas de Hispania. Madrid 1975, 30 Ss.; ID. Primitivas Religiones Ibericas. II. Religiones Prerromanas. Madrid 1983, 37 ss.; ID., La religión tartésica y fenicia del periodo orientalizante, en J.M. BLAZQUEZ ALII, Historia de las Religiones de la Europa antigua, Madrid 1994, 159 Ss.; M. BENDALA, Die orientalischen Religionen Hispaniens in vorrömischer un römischer Zeit, ANRW II/18.1, 1986, 352 sS.; M.C. MARIN CEBALLOS. Documents por l'étude de la religion phénico-punique dans la péninsule ibérique: Astarté, II Congrès International d'Etude des Cultures de la Méditerranée Occidentale II. Argel 1978, 21 ss.;

ID., La religión fenicio-púnica en España (1980-1993), HA 18, 1994, 533 ss

4) WATYEL, 1995, 163-165, pl. XIXb. 
otros documentos arqueológicos, en vaso apulio del Kunsthistorisches Museum de Viena, crátera del Museo de Malibú, lekythos del Hermitage, mangos de espejos de bronce de Locri y de Atenas, molde de vaso en metal de Hildesheim ${ }^{48}$. Con excepción de la citada moneda de Gortyna, datada en el siglo $\mathrm{V}$ a.C., de un relieve en oro de Bulla y del molde del Museo de Budapest, que se fechan en el siglo IV a.C., hay que esperar a las obras del siglo III a.C., como otro molde de metal de Hildesheim, las citadas monedas de Knossos, o terracota greco-babilonia ${ }^{49}$, para ver difundido el tipo iconográfico de Europa con el manto arqueado por encima de la cabeza, tipo que se generaliza en Occidente sobre todo del siglo I a.C. al II d.C. en pinturas pompeyanas, cerámicas, gemas, relieves y sigillatas ${ }^{50}$. La iconografía del velo arqueado sobre la cabeza se utiliza también en las representaciones de Aeternitas, junto a símbolos cósmicos, en monedas romanas; de Afrodita en su carácter astral como diosa de los planetas, y montada sobre el cisne, el macho cabrío o el delfín; de Natura; de las nereidas; y de las ninfas ${ }^{51}$. La contaminación iconográfica con algunas de estas figuras femeninas ha quedado plasmada también en las fuentes literarias, como Nonnos (Dion. I 55 ss.) cuando, al describir la travesia marina de Europa a lomos del toro, dice: “Al verla, uno creería que es Tetis, o Galatea, o la compañera del que sacude la tierra; o bien supondría que está viendo a Afrodita, sentada sobre la columna de un Tritón» 52.

El comienzo del viaje por el mar ofrece algunas variantes iconográficas respecto a la travesía marina propiamente dicha, ya que aunque el grupo formado por Europa a lomos del toro figure dentro del agua, aún aparece indicado el ambiente terrestre próximo al mar mediante rocas o la pradera florida e incluso en algunas representaciones el toro aún no galopa, sino que camina dentro del agua, como ocurre en el mosaico de Stabiae. En este grupo se encuadran el citado espejo de bronce del Ashmolean Museum, de comienzos del siglo I d.C., con indicación de un árbol detrás de la pareja formada por Europa y el toro que camina sobre la superficie del agua repleta de peces; y los pavimentos de Palestrina, Herculano y Stabiae, fechados en el siglo I d.C.,

"LIMCIV, «Europe 1", $n^{\circ} 72,74,93,98,100,103$

4: LIMC IV, "Europe l", nº 121, 90, 104, 109, 118.

56. Este tipo inconográfico se introduce en Roma en época augustea en las alegorias del Aire y del Agua del Ara Pacis, generalizándose el tipo en los sarcófagos a partir de Hadriano y de los Antoninos, cf. O. WATtEl-DE CRolzANt, Les mosaïques de Gaule et d'Espagne relatives à l'enlèvement d'Europe, /Conographie classique et identités régionales, BCH suppl. XIV, 1986, 185.

51 Cf. G.E. RIzzo, Aurae velificantes, BCAR LXVII, 1939, 141 ss., Tav. I-III; LIMC, "Aeternitas", $n^{\circ}$ 13, 14; "Aphrodite" IIIA 6c, tipo Urania; IVE; "Natura", no 1; "Nereides"; "Nimphai".

52 Cf. NONO DE PANOPOLIS, Dionisiacas. Cantos 1 -XII. Introducción. Traducción y Notas de S.M. Manterola y L.M. Pinkler, Bibl. Clás. Gredos 208. Madrid 1955, 59. 
donde se ha representado un paisaje terrestre, o los de Cannes, de la misma fecha ${ }^{53}$, y Mérida (Badajoz) con la aparición de la pradera florida.

El mosaico emeritense, datado en la segunda mitad del siglo II d.C., procede del solar de la ciudad y se conserva en el Museo de Arte Romano de Mérida ${ }^{54}$ (Fig. 25). La superficie del pavimento, de 4,45 x 2,90 m., se halla dividida en dos compartimentos bicromos. El umbral, de forma rectangular y $2,00 \mathrm{~m}$. de ancho, ostenta un cuadriculado de líneas de cuadrados sobre la punta, tangentes, con cruz de cuatro $\mathrm{T}$ inscrita en el

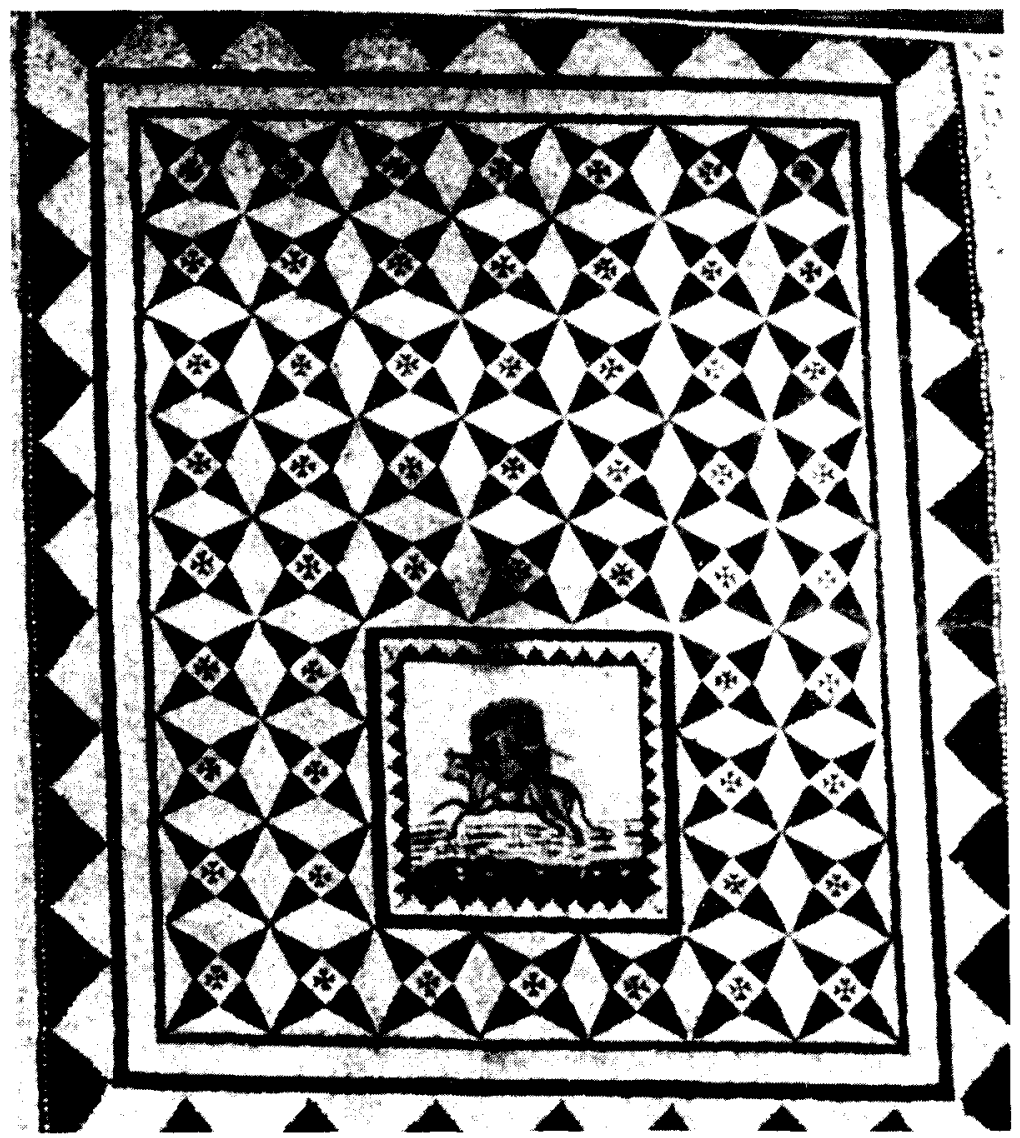

Figura 25. Mosaico de Mérida. Museo Nacional de Arte Romano de Mérida.

53 WATTEL, 1995, 73-85, 92-105, pl. VII, VIIIa y IX.

54 CMRE I, 1978, 28, nº 4, láms. 5 y 99. 
intervalo, en oposición de colores, dejando entrever la misma composición. El resto forma un cuadrado de $2,45 \mathrm{~m}$. de lado, bordeado por una orla de dientes de sierra en blanco y negro, con una composición ortogonal de estrellas de cuatro puntas tangentes, recargadas con un cuadrado inscrito por los vértices, formando rombos horizontales y verticales que dejan entrever octógonos secantes y tangentes ${ }^{55}$. El emblema policromo, cuya situación aparece descentrada dentro del cuadro pero centrada en relación a la superficie total del pavimento, forma un cuadrado de $0,92 \mathrm{~m}$. de lado, bordeado por otra orla bicolor de triángulos escalonados (Fig. 26). En él se ha figurado de manera muy sobria el comienzo de la travesía marina, como denota la alusión en primer término a la pradera florida. El grupo formado por Europa y el toro aparece galopando briosamente hacia

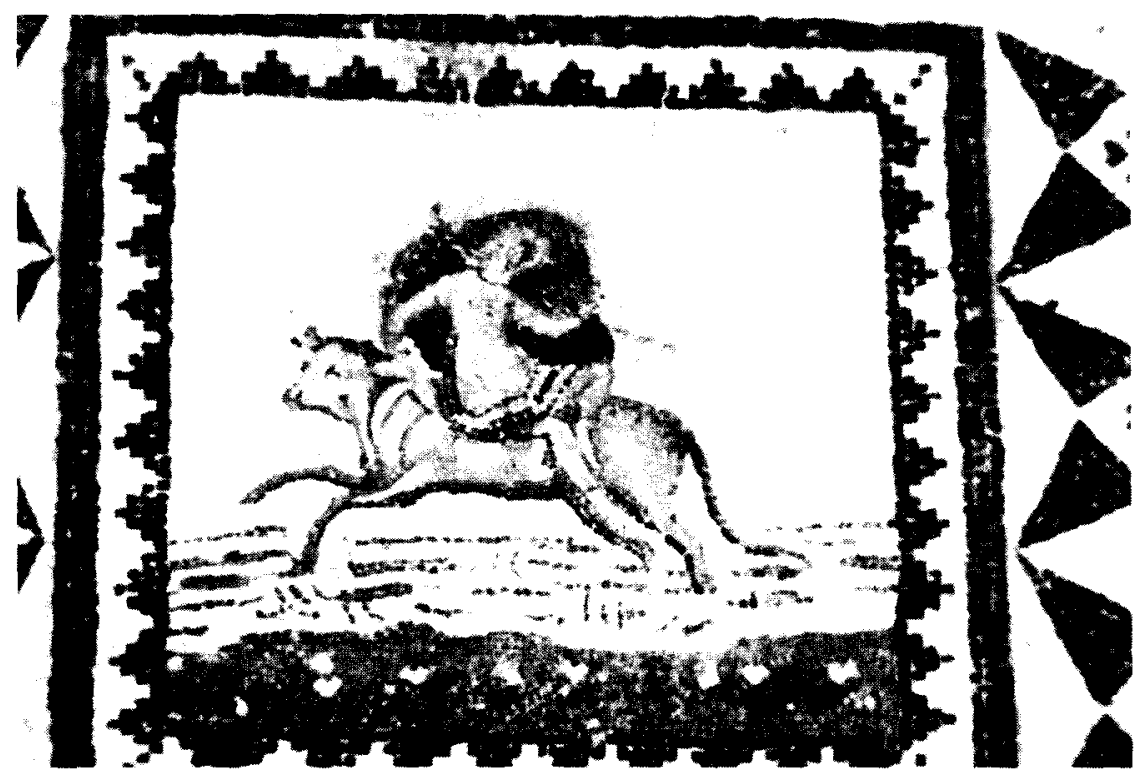

Figura 26. Mosaico de Mérida. Museo Nacional de Arte Romano de Mérida (Foto G. LOPEZ MONTEAGUDO).

la izquierda sobre la superficie marina. La princesa está vista de tres cuartos en posición frontal, montada a la amazona con una pierna flexionada y ligeramente reclinada sobre el dorso del animal; va totalmente desnuda excepto el pubis que cubre con el manto de color azul ribeteado en ocre;

55 G. BALMELLE ET Alli, Le décor gémetrique de la mosaïque romaine, Paris 1985, pl 184. 
con la mano derecha se agarra al cuerno del toro, mientras que con la izquierda sujeta el manto que se infla por detrás de la espalda y sobre la cabeza a efectos del impulso tomado por el animal en su huida precipitada hacia el mar, evocando de esta forma los relatos de Luciano de Samosata (Dial. mar. XV) y de Moschos (II 125 ss.). El toro ya no es el animal sumiso e inofensivo descrito por Ovidio (Met. II 855) de la primera etapa del mito, para no despertar el miedo en la princesa, sino que en este comienzo del viaje marino se ha convertido en un ejemplar que galopa briosamente por la superficie marina con la seguridad de haber conseguido su primer objetivo, que es el rapto de Europa, situación totalmente irreversible que desembocará en el final perseguido del hiéro gamos. La forma artística de representar al toro galopando briosamente sobre la superficie del agua sin penetrarla, que es la más frecuente, remonta al segundo estilo pompeyano y se impone como tipo iconográfico no antes de comienzos el siglo $\|$ d.C ${ }^{56}$.

El tipo iconográfico de Mérida se repite en otros emblemas musivos, como los de Tivoli y Fossombrone, datados respectivamente a comien-

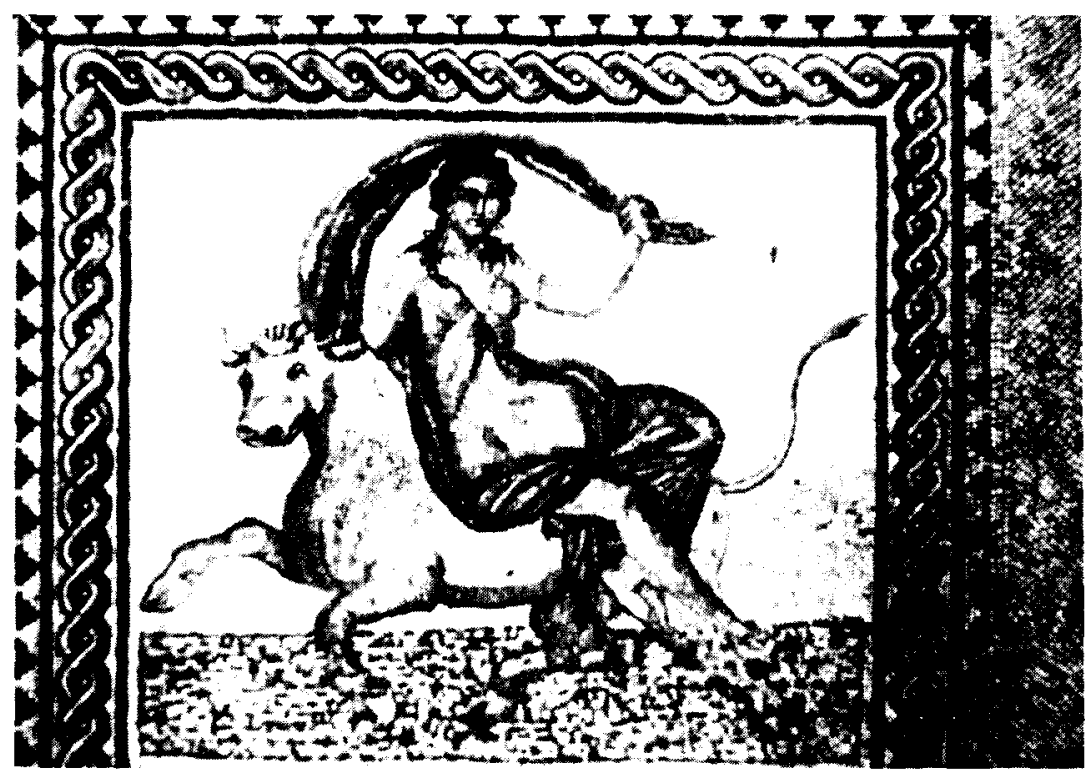

Figura 27. Mosaico de Arlès. Museo Lapidario de Arlés.

56 G.-CH. PICARD, Les thermes du thiase marine d'Acholla, Ant.Afr. 2, 1968, 142-143. 
zos del siglo II d.C. y en época constantiniana; de Poetovio, de comienzos del siglo Ill d.C.; de Arlès, encuadrable en el periodo antoniniano, con la particularidad de que aqui el toro galopa no como es habitual en este primer momento del rapto sobre la superficie marina, sino dentro del agua (Fig. 27), detalle que igualmente se aprecia en el pavimento de Corinto, de época severiana, si bien la poca profundidad de la misma en ambos ejemplos indica que el viaje marino no ha hecho más que comenzar; y de Amphipolis, datable a comienzos del siglo III d.C., donde la forma de representar al toro dentro del agua dejando ver solamente la parte que emerge de ella remonta a las pinturas helenísticas, y al mismo tiempo la profundidad y ondulación del agua parecen indicar ya un momento algo más avanzado del viaje por el mar, constituyendo por consiguiente un momento de transición entre las representaciones del comienzo de la travesia y el grupo siguiente, inmerso en un ambiente por completo marino ${ }^{57}$; en las estelas funerarias de Micia (Dacia) (Fig. 28), Novae (Noesia Inferior), Viminacium (Moesia Superior) y Celeia (Nórico), que se fechan en el siglo III d.C. ${ }^{58}$; en reversos de monedas de Gortyna y de Knossos, de los siglos $V$ y $I I I$ a.C. respectivamente, que llevan la cabeza de Zeus en el anverso o el laberinto en el reverso ${ }^{59}$; en monedas de Sidón de los siglos II a.C. al II d.C., de Creta, de época de Trajano, así como en otros ejemplares más tardios de Byzantium, Hadrianopolis y Seleucia de Cilicia ${ }^{60}$; y sobre todo en lucernas del tipo VII B de Deneuve, procedentes del N. de Africa, con una cronología en los siglos I-III d.C. ${ }^{61}$. En Hispania el tipo se repite en el citado as de Cástulo (Jaén) del siglo I a.C., conservado en la colección Real de Monedas y Medallas de Copenhague ${ }^{62}$ (vid. supra), y en lucernas romanas procedentes de Conímbriga, Bílbilis y Caesaraugusta ${ }^{63}$ (Fig. 16, 3-4).

57 Wattel, 1995, 119, 127-128, 141-143, 163-165, 171-174, PI. XIt b, XIV c, XV a, XIX a, $X X a-c, X X \vee b$.

I. Andritolu-L. Marghitan, Das archäologische Museum aus Deva, Bucuresti 1972, 51 , Taf. 59; L. PRESS-T. SARNOWSKI, Novae. Römisches Legioslager und frühbyzantinische Stadt an der unteren Donau, Antike Welt 21/4, 1990, 225 ss, Abb. 22; J.M.C. TorNBEE, Greek Myth in roman Stone, Latomus 36, 1977, 360-361, pl. IX, fig. 12.

54 A.E. JACKSON, The Bronze Coinage of Gortyn, Numismatic Chronicle XI, 1971, 37 ss. pl. 13: 1-2, 5-7, 14: 1-3; J.N. Svoronos, Numismatique crétois du Ve au ler siècle av. J.C., Bonn 1972, 59 SS., 153 ss., pl. VII: 8-14; XV: 22-23, 26-28.

60 LIMCIV, «Europe I", n 110,203 y 204.

61 LiMC IV, “Europe 1", no 193-196; G. López Monteagudo, M.P. San Nicolas Pedraz, La iconografía del Rapto de Europa en el Mediterráneo occidental. A propósito de una lucerna del Museo de Sassari, L'Africa romana VIII, Sassari 1991, 1005-1018.

62 SNG Copenhagen, 223-224.

6.3 C. BELCHIOR, Lucernas romanas de Conimbriga, Coimbra 1969, 49, no 97, Est. X, 5; M.T. AMARE, Lucernas romanas de Aragón, Zaragoza 1988, figs. 100-101, Jáms. IX, 13 y XI, 1. 


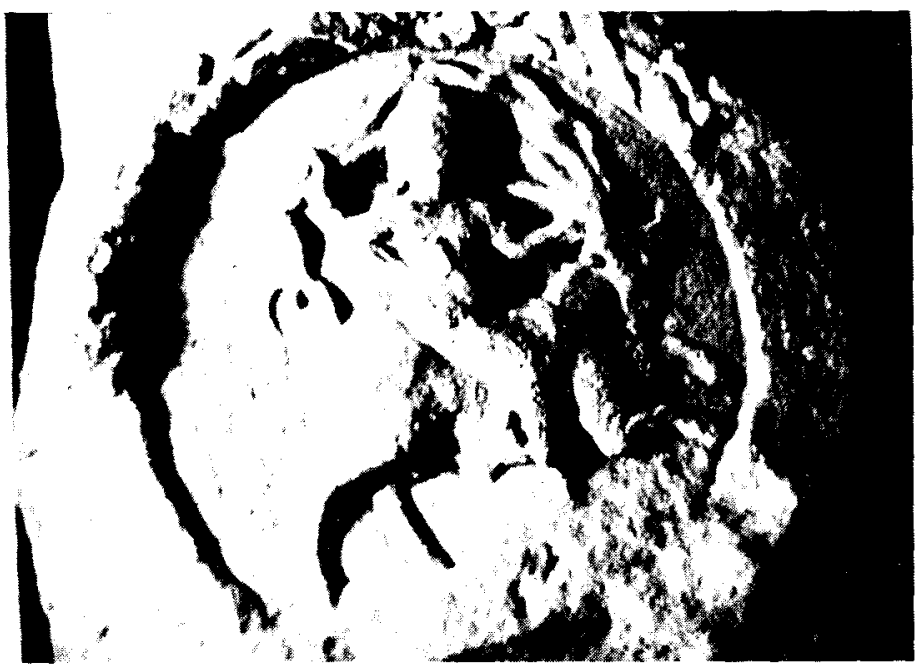

Figura 28. Estela funeraria de Micia.

La elección del rapto de Europa con un sentido escatológico, ya sea como decoración de estelas funerarias o de lucernas y terracotas procedentes de contextos funerarios, ha sido puesta en relación con el simbolismo del mito como vía de acceso a la inmortalidad a través de la exaltación del amor.

La tercera fase del mito o travesia marina, evocada en los Himnos Orficos de Hesiodo (od. XXXV) y en los relatos de Luciano de Samosata (dial. mar. XV), Moschos (II 125 ss.), Horacio (od. III 27) y Ovidio (Fast. V 607-610), es la más representada en cerámicas, mosaicos, lucernas y terracotas, con gran amplitud cronológica y numerosas variantes iconográficas, aunque en todas ellas queda de manifiesto el cambio efectuado durante la travesía marina en los sentimientos de la princesa sidonia ${ }^{64}$. En efecto, Europa ya no aparece ni asustada ni sorprendida, sino que en actitud relajada manifiesta su atracción amorosa por el toro, pasión que le ha sido insuflada por los erotes siempre presentes como simbolos del amor, aunque a veces su presencia forzada por el soporte, esté solamente sugerida por la antorcha, como ocurre en el citado espejo del Ashmolean Museum.

64 LIMC IV, "Europe 1", p. 76 ss.; G. López Monteagudo, M.P. San Nicolas Pfdraz, La iconografia del Rapto de Europa en el Mediterráneo occidental. A propósito de una lucerna del Museo de Sassari, L'Africa romana VIIt, Sassari 1991, 1.005-1.018. 


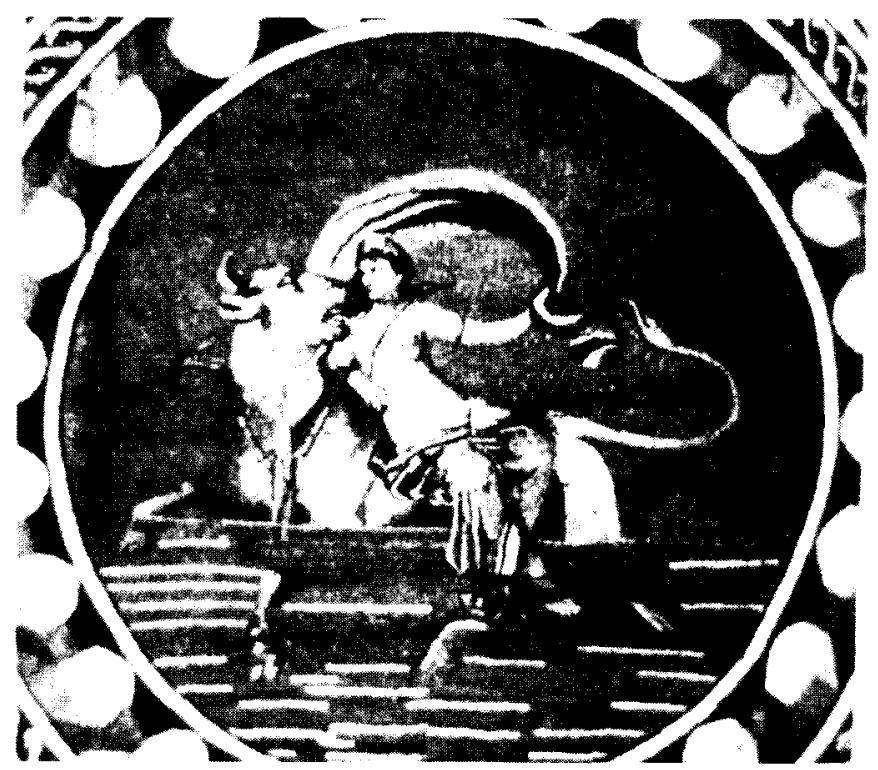

Figura 29. Mosaico de Tor Tre Treste. Ny Carlsberg Glyptoteca de Copenhague.

La relación amorosa entre la princesa sidonia y Zeus metamorfoseado en toro se atestigua en los mosaicos de Tor Tre Treste, conservado en la Ny Carlsberg Glyptoteca de Copenhague, que se fecha en el siglo I-II d.C. (Fig. 29), y de Lípari, de época severiana, en los que el toro vuelve voluptuosamente la cabeza hacia Europa ${ }^{65}$. El mismo tipo iconográfico se repite con algunas variantes en otros pavimentos, como en los mosaicos argelinos del siglo IV d.C. procedentes de Djemila, donde Europa ofrece al toro un cesto de comida, mientras que los erotes agarran al animal por la cola (Fig. 30), detalle este último que también se documenta en el pavimento de Lullingstone, de la misma fecha; y de Macomades, en el que se ha representado a la princesa desnuda y sentada a la jineta, que besa al toro cogiéndole la cabeza (Fig. 31), confirmando de esta forma los versos de Anthipater (epigr. amor. de la Anthologia Palatina V ep. 109) y de Nonnos (Dionys. I 65-67) ${ }^{66}$.

Se inicia asi todo un proceso amoroso bien patente en las escenas reflejadas en la cerámica griega de figuras rojas, donde el pintor de Berlín crea un tipo iconográfico nuevo que aparece también en vasos áticos,

65 WATTEL, $1995,120-127$, pl. XIII a y XIVa.

b6 WATTEL, 1995, 191-194, 223-227, pl. XXIII, XXX a-b. 


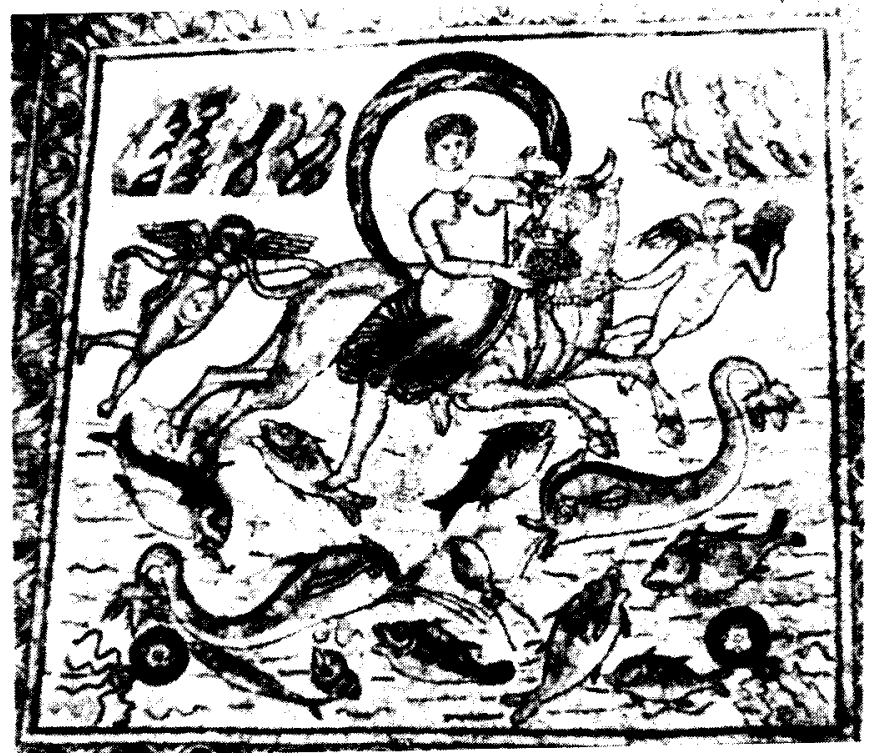

Figura 30. Mosaico de Djemila. Museo de Djemila

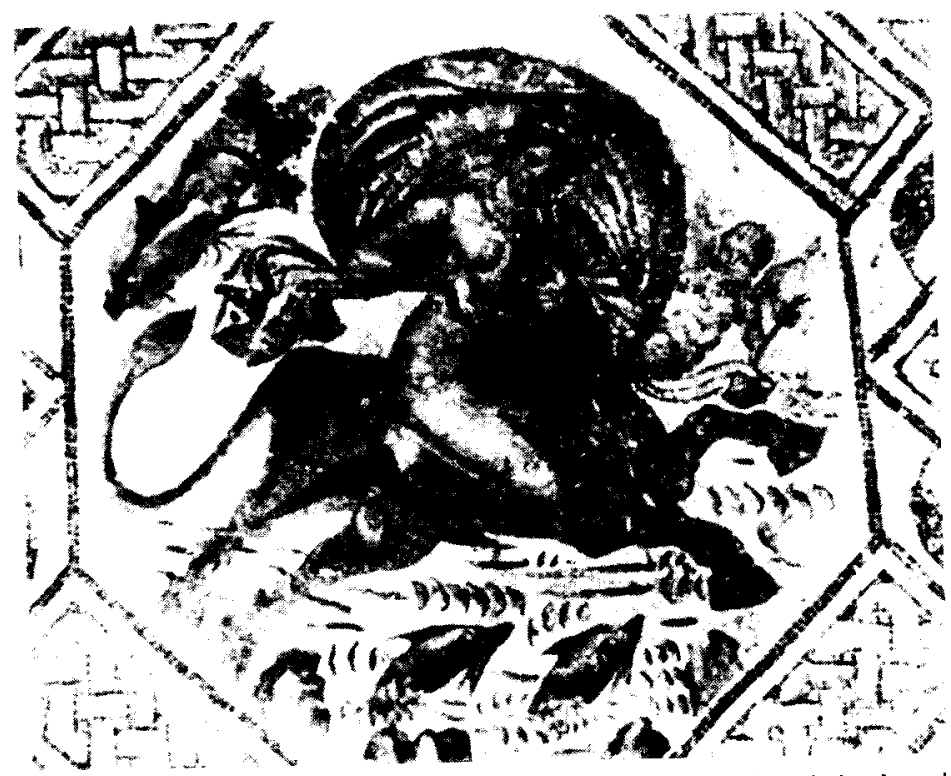

Figura 31. Mosaico de Macomades. Museo Nacional de Argel. 


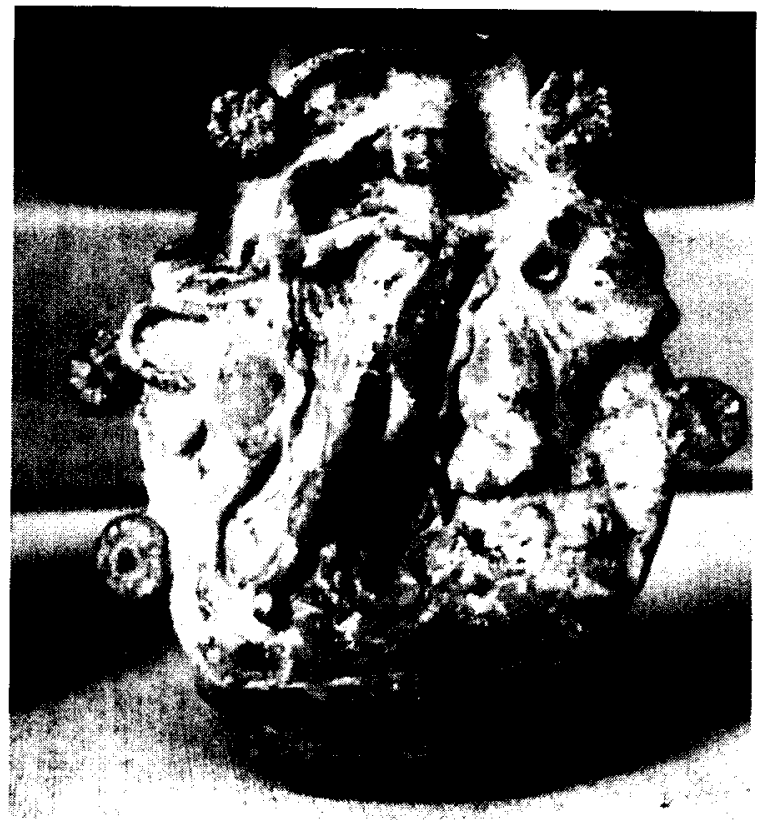

Figura 32. Vaso ático. Pergamonmuseum de Berlin. (Foto G. López MonteAGudo).

como el conservado en el Pergamonmuseum de Berlín, de la primera mitad del siglo IV a.C. (Fig. 32), en moldes de vasos en metal procedentes de Creta y Hildesheim, de la misma época, y en terracotas del periodo helenístico, como el grupo procedente de Tarento que se guarda en el Akademischer Kunst de Bonn; y va a perdurar en obras posteriores, como en un espejo de bronce de los siglos III-IV d.C. ${ }^{67}$ (Fig. 33). En todas ellas la princesa sidonia ya no está sentada sobre el toro sino que flota a su lado agarrándose al cuerno del animal. Este tipo iconográfico evoluciona en época romana creándose variantes de gran contenido erótico al aparecer Europa recostada sobre el dorso del animal o flotando desnuda o semi desnuda al lado del toro, al que agarra por el cuello para besarle, como ocurre en pinturas de Stabiae y Herculano, de comienzos y primera mitad del siglo I d.C.; de la Domus Aurea y de Pompeya, de los años 60 y 70 d.C. (Fig. 34); así como en mosaicos de Cos, datados en siglo III d.C. ${ }^{68}$ (Fig. 35). En estas escenas, donde la violencia del rapto ha sido sustituida

67 WatTEL, 1995, 26-32, figs. 7-9; LIMC IV, “Europe I», no 72, 99, 103, 199.

68 LIMC IV, “Europe I", $\mathrm{n}^{\circ}$ 128-141; WATTEL, 1995, 174-176, pl. XXI a. 


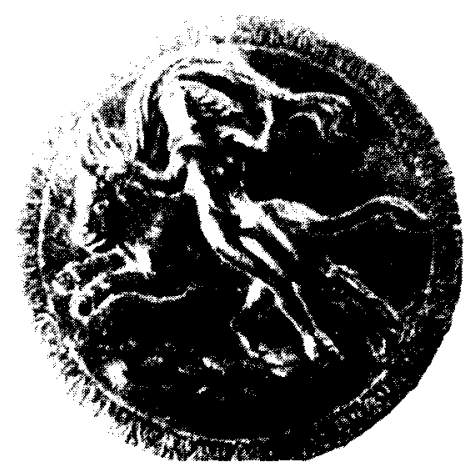

Figura 33. Espejo de bronce. Col. privada inglesa.

por la intimidad de la atracción amorosa, el animal vuelve a mostrar la apariencia sumisa e inofensiva que tenía en la primera etapa del mito, alejándose del tipo iconográfico del toro que, tras perpetrar el rapto, galopa con jactancia sobre el agua.

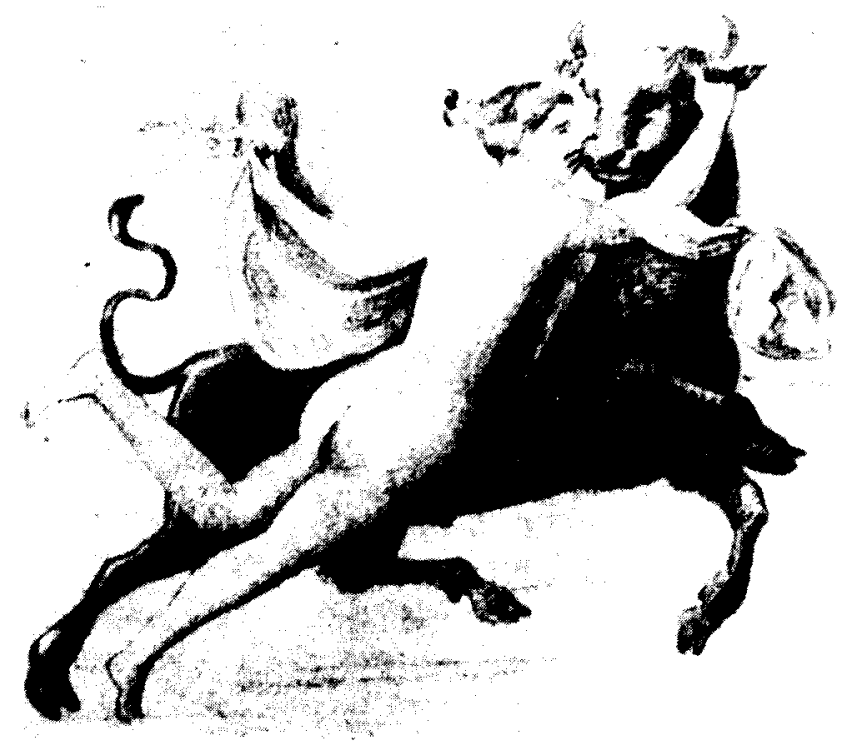

Figura 34. Pintura pompeyana destruida. 


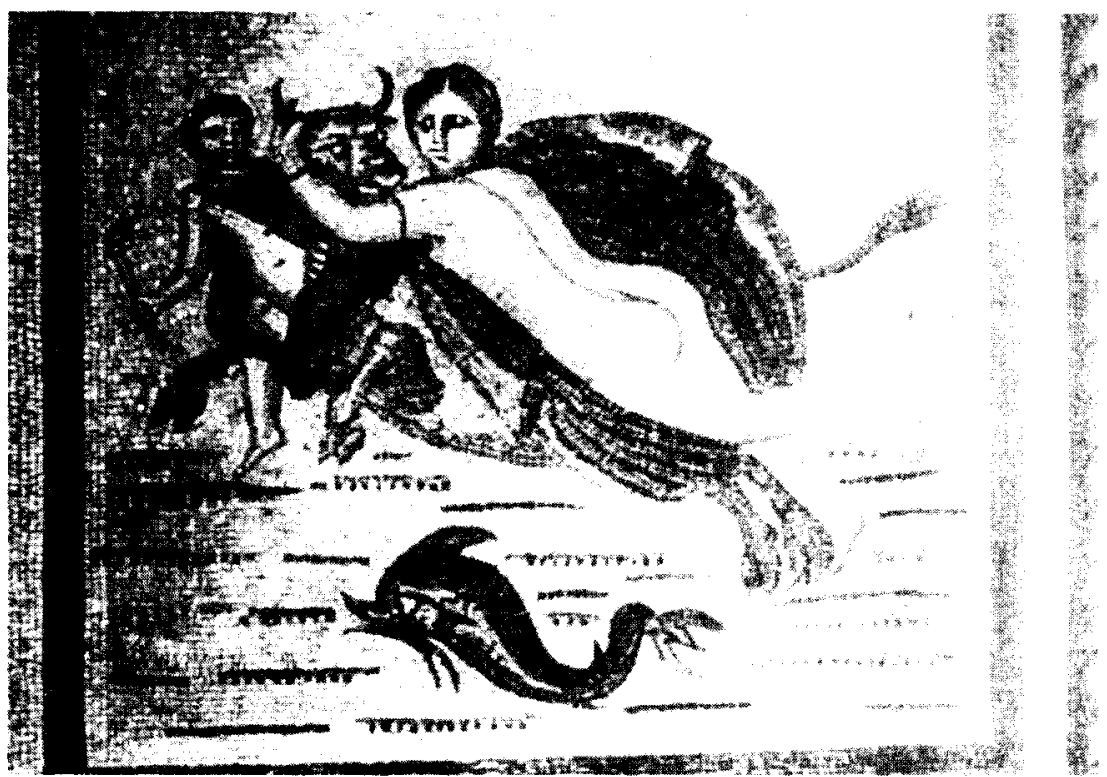

Figura 35. Mosaico de Cos. In situ.

Los dos mosaicos hispano-romanos pertenecientes a este grupo iconográfico proceden de dos casas romanas del siglo III d.C., descubiertas en fechas recientes en el subsuelo de la ciudad de Ecija (Astigi), con la particularidad de que ambas escenas formaban parte de un programa iconográfico de carácter báquico ${ }^{69}$, como ocurre con otras representaciones del rapto de Europa, baste recordar el pavimento tardío de Sarrîn (vid. infra), dentro del simbolismo del mito y del ritual dionisiaco ${ }^{70}$. Las bodas «místicas", el hiéro gamos de Zeus y Europa o de Baco y Ariadna, simbolo de la unión entre lo divino y lo humano, garantizan la fecundidad a través de la cual se alcanza la eternidad, convirtiéndose de esta forma en alegorías de inmortalidad.

El primer pavimento decoraba una habitación de $2,5 \mathrm{~m} 2$, adyacente al mosaico del Triunfo báquico ${ }^{71}$ (Fig. 36). Enmarcada por una orla de oji-

69 G. Lopez Monteagudo Et AlII, Recientes hallazgos de mosaicos romanos figurados en Hispania, VII Coloque International pour l'Eude de la Mosaique Antique (TLinez 1994), en prensa. Agradecemos a Dña. Esther Núnez las noticias proporcionadas sobre los hallazgos de Ecija, asi como las fotografías que aquí se publican.

70 J. Balty, La mosaïque de Sarrín (Osthoène). Paris, 1990, 87-102.

71 1. Rodriguez TeRmino, E., NUNez PARIENTE dE LEON, Arqueologia urbana de urgencia en Ecija (Sevilla), 1985, Anuario Arqueológico de Andalucia III. Actividades de Urgencia, 1985 (1987), 321-325. 
vas polícromas, la superficie del pavimento consta de una zona rectangular en la parte inferior, decorada con red de cuadrifolios ${ }^{72}$; la parte superior, de forma cuadrada, constituye el emblema figurado rodeado de una línea de dientes de sierra dentellados polícromos, seguida de un sogueado de tres cabos también polícromo. En el cuadro se ha representado una escena del rapto de Europa de gran interés iconográfico ya que si bien la presencia del eros, que desde tierra impele al animal a salir hacia el agua, podria sugerir el comienzo de la travesía marina del rapto de Europa, sin embargo el grupo formado por el toro y la princesa sidonia, cabalgando briosamente dentro del agua hacia la derecha, la actitud relajada de Europa y los elementos marinos presentes en la escena, ofrecen todas las características del viaje marino propiamente dicho. Estamos, pues, en presencia de un cuadro "abreviado", en el que a través de unos cuantos elementos iconográficos se intenta contar, si no todo, sí parte del relato mítico: el trozo de tierra con el árbol hace referencia a los prolegómenos del rapto en tierra firme; la actitud de violento movimiento del eros alado, fustigando desde tierra al animal, que recuerda al representado en el mosaico de Fernán Núñez (vid. supra), sugiere

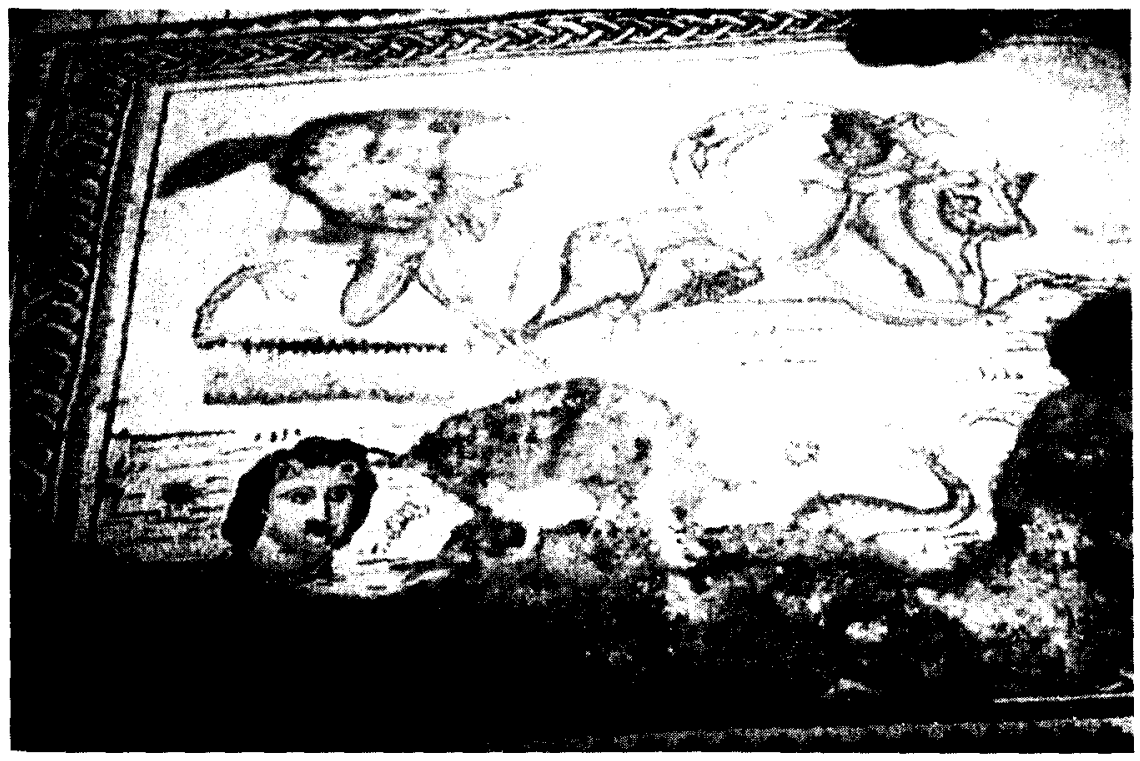

Figura 36. Mosaico de Ecija. (Foto cortesía E. NúnEZZ).

\footnotetext{
7. C. Balmelle Et Alil, Le décor géométrique de la mosaique romaine. Paris 1985 pl. 131.
} 
el momento mismo del rapto cuando el toro salta hacia el mar; Europa aparece representada de forma canónica agarrando con la mano derecha el cuerno del animal, mientras que con la izquierda sujeta sobre la cabeza el velo de color azul que se arquea por detrás de su espalda insuflado por el viento; pero su postura recostada sobre el dorso del toro y su desnudez solo en parte cubierta por el himation transparente que cae sobre sus piernas y deja al descubierto el resto del cuerpo, impregnan a la escena de un cierto erotismo sugiriendo que la princesa ya ha experimentado el sentimiento de atracción amorosa por el toro, proceso que tiene lugar en plena travesia marina como indica la profundidad y el movimiento del agua, dentro de la que galopa briosamente el toro, y los animales marinos en ella representados.

La forma de representar al toro dentro del agua es típica de las pinturas helenísticas, que muestran solo la parte del cuerpo del animal que emerge del agua ${ }^{73}$, y se vuelve a encontrar en los mosaicos de Amphípolis y Rodas, contemporáneos del pavimento de Ecija ${ }^{74}$. En éste llama además la atención los cuernos del toro en forma de creciente lunar, detalle que también se aprecia en los mosaicos de Fernán Núñez (vid. supra) y Byblos, de finales de época severiana, Daphne, de comienzos del IV d.C., y Sarrîn, ya del VI d.C. ${ }^{75}$, seguramente aludiendo al origen oriental del mito y a la posible hipóstasis de Europa con Astarté ${ }^{76}$.

La postura recostada de la princesa no tiene paralelos en mosaicos, puesto que la figura femenina del pavimento de Naxos, fechado en el siglo IV o $V$ d.C., que podría constituir el tipo más próximo, puede interpretarse tanto como Europa o como una nereida, ya que aunque cabalga un toro marino con "cola de pescado", tal como lo describe Nonnos (Dion. 1 79-80, 101-102), sin embargo no ofrece los elementos iconográficos característicos del viaje por mar, como es la forma de agarrarse al cuerno del animal y el velo inflado por el viento ${ }^{77}$. Los únicos paralelos aducibles serían una terracota de finales del siglo II d.C., donde Europa va totalmente desnuda, sin manto y llevando una corona de flores en la mano derecha, mientras con la izquierda se agarra al cuerno del toro, y el citado relieve sobre disco de bronce del siglo III-IV d.C ${ }^{78}$.

\footnotetext{
G.-CH. PICARD, Les thermes du thiase marine d'Acholla, Ant.Afr. 2, 1968, 142-143.

WATTEL, 1995, 173-174, 182-183, pl. XX c y XXII b.

WATTEL, 1995, 201-207, pl. XXV a-b, XXVI b.

76 G. Lopez Monteagudo-M.P. San Nicolás Pedaaz, Astarté-Europa en la Peninsula lbérica. Un ejemplo de interpretatio romana, Homen. M. Fernández-Miranda (en prensa).

77 WATTEL, $1995,180-182$, XX11 a.

78 LIMC IV, "Europe I", no 191 y 199.
} 
Sin embargo, 10 más destacable en la escena astigitana es la cabeza de sátiro que emerge del agua en la parte de la izquierda, debajo de la línea de tierra, con abundante cabellera de color negro, orejas leoninas y una especie de collar al cuello, que constituye un unicum en este tipo de representaciones y que refuerza el carácter báquico del mito de Europa.

En este tercer episodio del mito, que relata el viaje de Europa por el mar a lomos del toro, la introducción de elementos marinos como los peces, las nereidas o los tritones, p.e. en cerámicas áticas de 370-360 a.C., crátera de Paestum de ca. 330 a.C., o en pintura pompeyana de hacia el 70 a.C. ${ }^{79}$, e incluso la presencia de Neptuno y la misma iconografía del toro en forma de animal marino (Nonn. Dion. I 79-80, 101-102), documentado en los mosaicos de Aquileia, Nimes, Henchir-Thina y Naxos, fechados respectivamente en el siglo II, comienzos del siglo IV y IV-V d.C. ${ }^{80}$, produce una cierta confusión a la hora de distinguir a Europa de otras figuras femeninas como bacantes y nereidas. La presencia de Poseidón en el mosaico de Aquileia se justifica por el papel que algunos mitógrafos (Clem. Al. Prot. 27; Schol. Germ. Arat. Phaenom. 11 55) le asignan en la leyenda, al haber sido este dios el que había puesto el toro cretense a disposición de Zeus para su aventura con Europa. También la leyenda se hace eco de una Europa hija de Tityos, que se convirtió en amante de Poseidón metamorfoseado en toro (Pind. Pyth. IV 44; Apolon. de Rodas, Argon. 1 181) ${ }^{81}$; y en Hesiodo (Theog. 357) Europa es una hija de Océanos y Tetis. Solo ciertos atributos, como las flores o el cesto que recuerdan la ocupación de la princesa sidonia en el momento del rapto (Mosch. II 30-99), o la presencia en la escena de Eros, simbolo de la pasión amorosa de Zeus por Europa (Ach. Tat. 16 ), permiten una identificación segura. Desde el punto de vista iconográfico algunas representaciones de Europa, acompañada del séquito triunfante de la procesión marina (Luc. Sam. Dial. Mar. IX $15,2)$, se hallan muy próximas a las Venus marinas africanas y es que, como afirma D. Levi, los temas de Europa sobre el toro y del thiasos marino están conectados y son intercambiables ${ }^{82}$. La contaminación del rapto de Europa con el thiasos marino y su presencia en termas ha sido puesta por G.-Ch. Picard en relación con el valor profiláctico de estos personajes conectados con las aguas, como símbolos de la prosperidad y riqueza buscadas por los comerciantes que frecuentaban esos lugares ${ }^{83}$.

\footnotetext{
79 LIMCIV, "Europe $1 ", n^{\circ} 59,60,74$ y 142.

8O WATTEL, 1995, 115-118, 143-145, 180-182 y 221-222, pl. XI, XV b, XXII b y XXIXb.

" Cf. DAGR II, 863. Sobre la relación de Europa con el medio marino vid supra.

B2 D. LEVI, Antioch Mosaic Pavements, Priceton 1947, 172.

B3 G.-CH. PICARD, La civilisation de l'Afrique romaine, Paris 1959.
} 
El segundo mosaico de Ecija decorado con el rapto de Europa procede de otra casa romana pavimentada con mosaicos, entre los que destaca una magnífica escena báquica presidida por la figura del “Tigerreiter» ${ }^{84}$. El primero, que sufrió la tercera compartimentación espacial de la domus con la construcción de un muro por encima del mismo, ostenta una distribución de su superficie muy parecida al otro pavimento astigitano decorado con el rapto de Europa, descrito anteriormente. El campo del mosaico, enmarcado también por una orla de ojivas, ofrece una zona decorada con damero en oposición de tres colores. El resto del espacio, de forma cuadrada, lo ocupa una composición de esquema a compás realizada mediante sogueado de dos cabos ${ }^{85}$ (Fig. 37). La escena con el Rapto de Europa ocupa el medallón central, estando decorados los tres medios círculos que se conservan con figuras báquicas recostadas en un paisaje de arbustos: ménade con tirso y dos personajes masculinos con

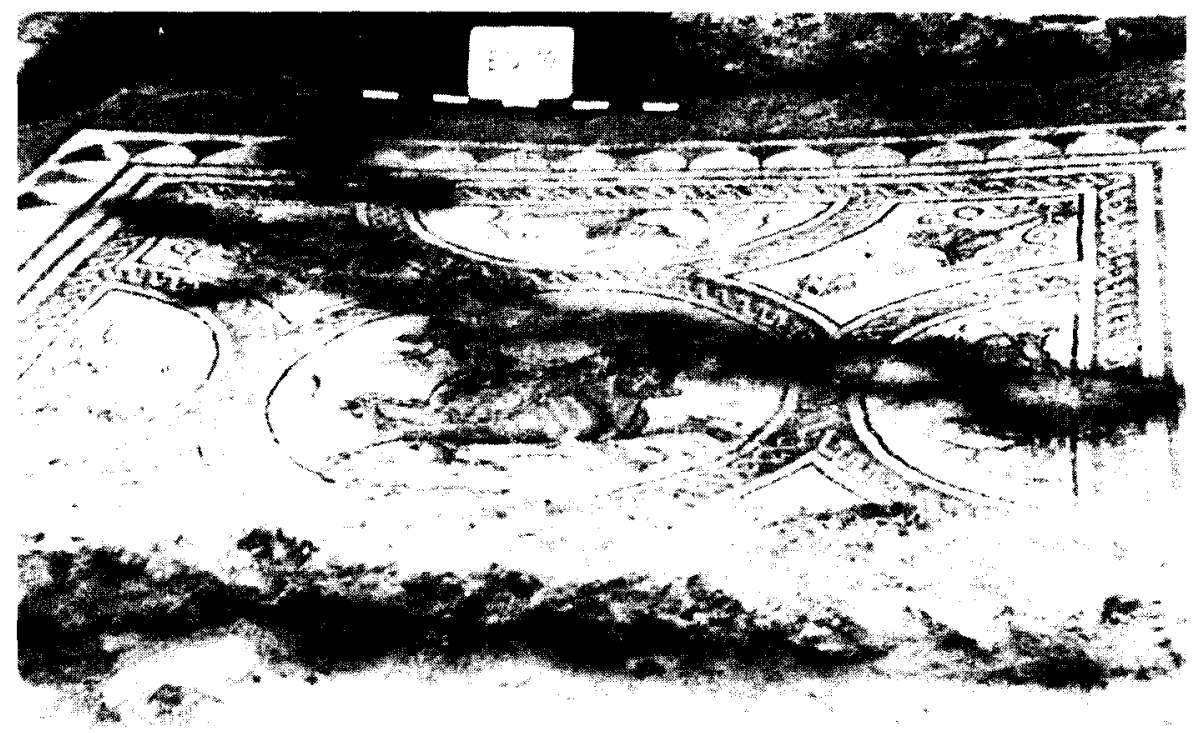

Figura 37. Mosaico de Ecija. (Foto cortesia E. NúNEZ).

84 E. Nunez Pariente de León, "Intervenciones arqueológicas en Ecija, 1991", Anuario Arqueológico de Andalucia III. Actividades de Urgencia, 1991 (1993), 489, láms. 3-4.

85 G. SALIES, "Untersuchungen zu den geometrischen Gliederungschemata römischer Mosaiken", BJb 174, 1974, 14-15, 157-162, Bild 4, Kreissystem I a, Zentralkompostion; D. Fernández Galiano, Mosaicos hispanos de esquena a compás, Guadalajara, 1980. 
nebris y pedum, mientras que putti surgiendo de un tallo de acanto ocupan los espacios de los ángulos. La composición del mosaico y la decoración de los medios círculos, lo aproximan de forma sorprendente al pavimento de la Loba y los Gemelos de Alcolea (Córdoba), que se se fecha en el siglo II d.C. ${ }^{86}$.

Como en el otro pavimento astigitano, aquí también se ha representado la tercera fase del rapto, insistiendo en el caracter erótico del viaje marino, pero con un contenido menos narrativo y una iconografía algo distinta (Fig. 38). Europa aparece flotando de espaldas sobre el toro, que galopa dentro del agua hacia la derecha; la princesa sidonia va totalmente desnuda, sujetando con la mano derecha sobre su cabeza el manto de color azul transparente que, flotando por detrás de la espalda, cae sobre las piernas, mientras que con la mano izquierda se agarra al cuerno del animal; en la parte alta, muy deteriorada, se aprecia un Eros alado que vuela tras el grupo fustigando al animal, cuyo cuerpo se deja ver a través del agua indicada mediante líneas de color azul-verdoso, como ocurre en las pinturas pompeyanas y en los mosaicos de Tor Tre Treste, conservado en la Ny Carlsberg Glyptoteca de Copenhague, que se fecha en el siglo 1II d.C., Arlès, encuadrable en el periodo antoniniano, Corinto, de época severiana, y Salzburgo, de comienzos del siglo III d.C. ${ }^{87}$.

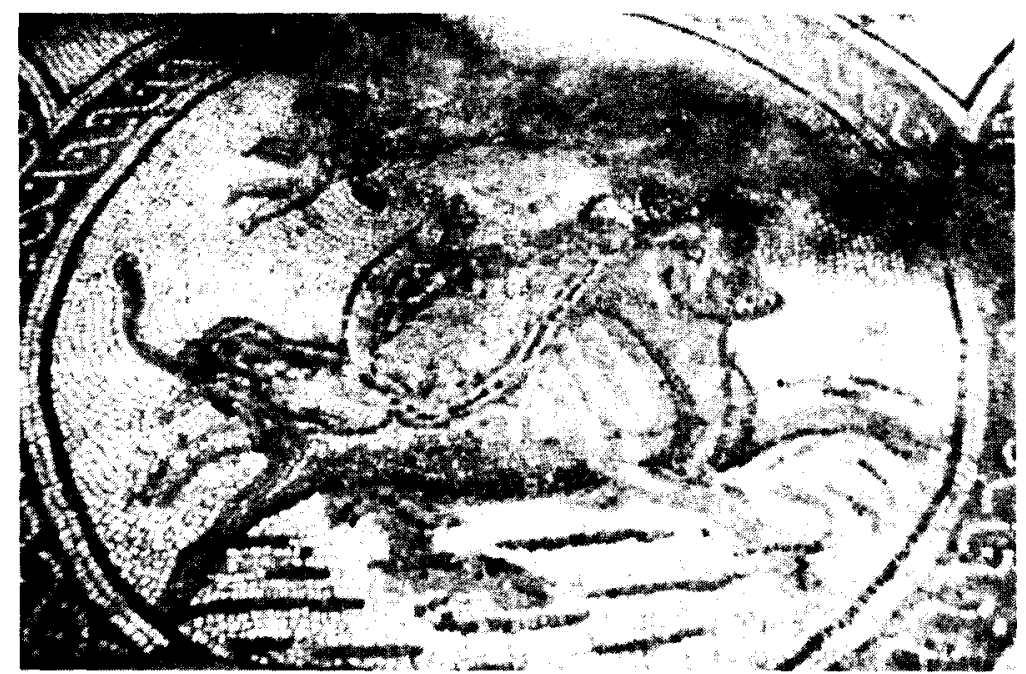

Figura 38. Mosaico de Ecija. (Foto cortesía E. NUNNEZ).

86 CMRE III, 1981, 43-46, ñ23, láms. 32-34, 89.

87 WATTEL, 1995, 62-63, 120-123, 141-143, 163-165, 171-173, PI. V a, XII a, XIV c, XV a, XIX b, XX a-b. 
Tipológicamente esta representación hispana del rapto de Europa se encuentra muy próxima a los pavimentos de Cos, de la primera mitad del siglo III d.C., donde la princesa aparece totalmente desnuda flotando de espaldas sobre el costado del toro; con su mano derecha rodea el cuello del animal que vuelve la cabeza hacia ella, mientras que con la izquierda se agarra al cuerno; detrás del grupo se ha representado un eros con antorcha, que acentúa el contenido erótico de la escena ${ }^{88}$. Idéntico tipo iconográfico se repite en pinturas de Herculano y de Pompeya, aunque los paralelos más próximos para el grupo de Ecija se documenta en moldes de vasos en metal de los siglos IV y III a.C. y en un ágata del Cabinet des Médailles de Paris que se fecha en los siglos 1II d.C. En todos ellos, la princesa aparece flotando al lado del toro o sobre el dorso, haciendo el gesto de levantar el velo por detrás de la espalda, en los primeros, o sosteniendo una corona de flores en el ágata ${ }^{89}$.

En este grupo tipológico de carácter erótico del rapto de Europa, al que pertenecen los mosaicos de Ecija, se encuadra también una terracotta hispana bastante fragmentada, procedente de Sisapo (Ciudad Real), que se fecha en la segunda mitad del siglo I d.C. ${ }^{90}$ (Fig. 39). El grupo de pequeño
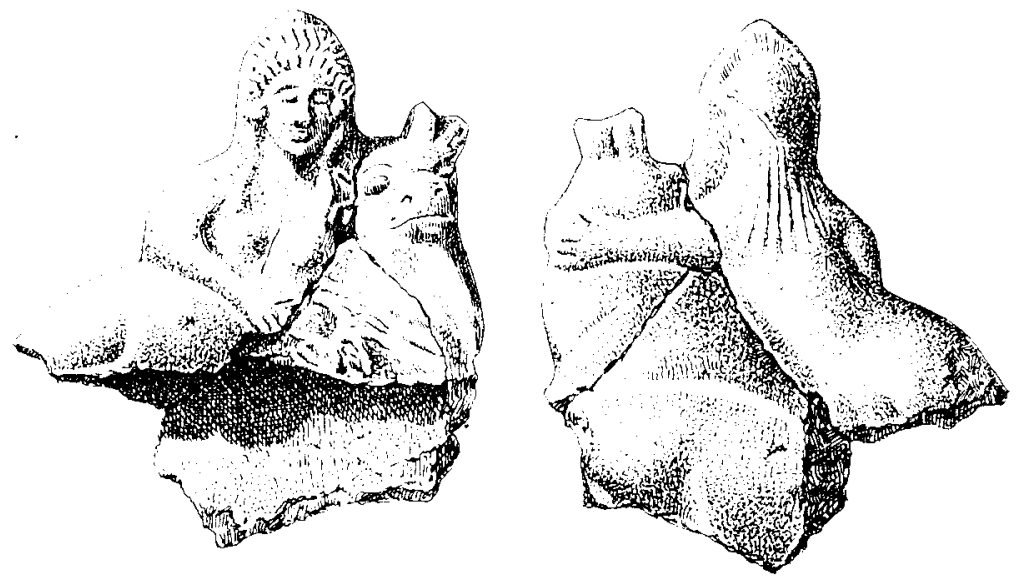

Figura 39. Terracota de Sisapo. (Dibujo M.P. SAN NICOLÁS PEDRAZ).

\footnotetext{
${ }_{88}$ Wattel, 1995, 174-176, pl. XXXI a; E. Brouscari, Nouvelles Mosaíques de Cos, VII Coloque International de ia Mosaïque (Tumis 1994), en prensa.

89 LIMC IV «Europe I", nº 128-141, 99, 103, 188, WATTEL, 1995, 62-64, pl. IV c y Vb.

90 G. Lopez Monteagudo, M.P. San Nicolas Pedraz, La iconografía del Rapto de Europa en el Mediterráneo occidental. A propósito de una lucerna del Museo de Sassari, L'Aírica romana VIII, Sassari 1991, 1.015, fig. 5; C. Fernandez OChOA, M.P. San Nicolas, Terracotas romanas de Sisapo (La Bienvenida, Ciudad Real), Homen, al Prof. J.M. Blázquez, en prensa.
} 
tamaño, solo tiene $8,9 \mathrm{~cm}$. de altura, ofrece un alto contenido erótico al aparecer Europa completamente desnuda y recostada sobre el dorso del animal; la princesa lleva en su mano derecha una guirnalda de flores, mientras que con el brazo izquierdo se abraza de forma voluptuosa al cuello del toro que vuelve la cabeza hacia ella con un gesto de seducción amorosa.

Al parecer, en todas estas escenas se ha querido representar la última fase del mito que culmina con la hierogamia de la pareja, simbolizada de forma alegórica en las dos coronas que sostiene en sus manos el personaje alado que aparece detrás del grupo formado por Europa y el toro en una hidria de Caere del Museo de villa Giulia, datada en 530-520 a.C.; en el mosaico de Esparta, fechado a fines del siglo III o a comienzos del IV d.C., donde dos erotes sostienen el velo arqueado sobre Europa y el toro, como símbolo de la unión amorosa entre ambos (Fig. 40); así como en el pavimento de Rodas, del siglo IV d.C., donde el nimbo que rodea la cabeza de Europa alude posiblemente a la divinización de la princesa a través del hiéro gamos, tras la llegada a tierra firme someramente indicada por un trozo de tierra que el toro pisa con su pata izquierda ${ }^{91}$.

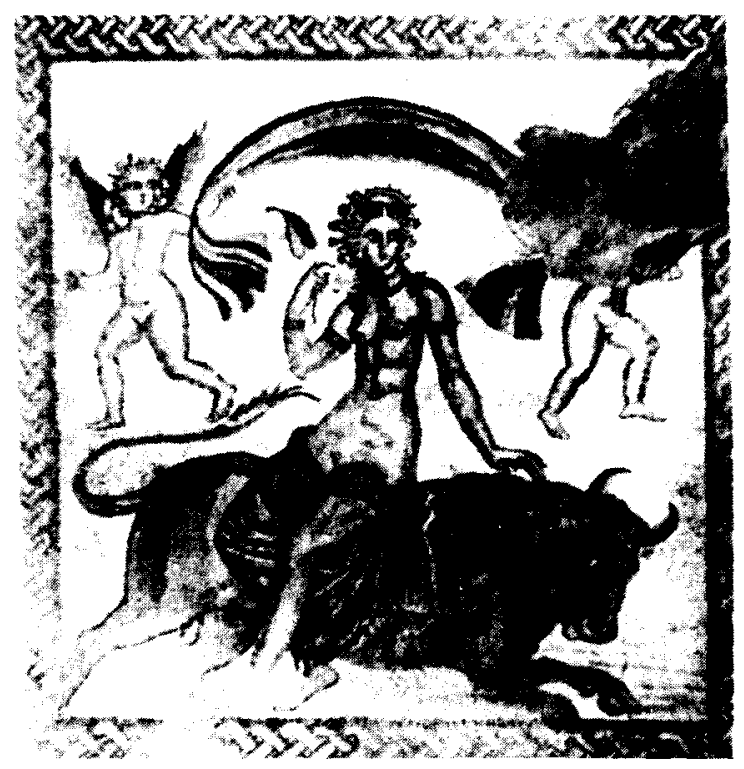

Figura 40. Mosaico de Esparta. In situ. 
La llegada a tierra firme, donde se consuma la hierogamia, ha quedado plasmada en otra hidria de Caere del Museo del Louvre, del 530 a.C., en la que se muestra a la pareja divina arrivando ante un montículo terrestre sobre el que se levantan tres árboles que aluden a los plátanos de Gortyna y a la unión amorosa ${ }^{92}$. De los momentos que siguen a la llegada a tierra existen algunos documentos iconográficos, como un relieve de marfil de Egipto (?) de la primera mitad del siglo VI d.C., en el que se representa a Europa que, en pie y vestida con peplos transparente, abraza y besa al toro cabalgado por un pequeño erote, en presencia de otros dos amorcillos ${ }^{93}$. El momento previo a la unión, si es que no se trata de la primera fase del mito, parece representarse en státeras de Phaistos, de comienzos del siglo IV a.C., en cuyo anverso Europa aparece ya sentada en una roca recibiendo al toro que se le aproxima desde la izquierda ${ }^{94}$.

La hierogamia de Europa y Zeus, que según las fuentes literarias (Theophr. HP 195; Varr. RR 17,6; Plin. NH XII 11; Antig. Mir. 163), tiene lugar en Creta bajo el plátano siempre verde de Gortyna, solo se halla atestiguada arqueológicamente en reversos de dracmas y didracmas de plata del siglo IV a.C. y en anversos de óbolos de bronce del siglo III a.C. de esta ciudad (Fig. 41): Europa aparece sentada sobre al árbol o echada a la sombra del plátano, en actitud pensativa y melancólica, mientras que en el anverso de las primeras se ha representado al toro divino y en el reverso de los segundos a Europa cabalgando sobre el toro sujetando el velo arqueado sobre la cabeza ${ }^{95}$. W. Bühler opina

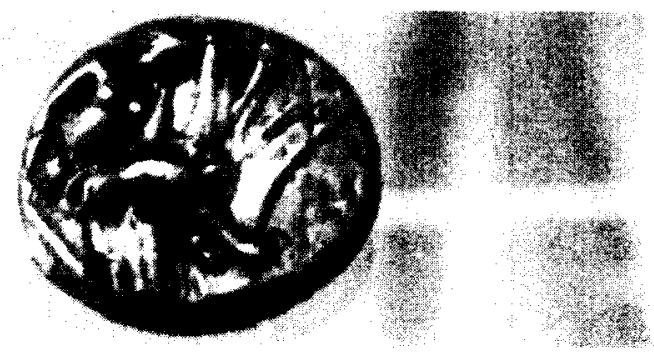

Figura 41. Moneda de Gortyna. Museo Kestner de Hannover. (Foto G. LOPEZ MONTEAGUDO).

92 LMC IV, "Europe 1", nº 23; WaTtEL, 1995, 25, fig. 6.

93 K. Weitzmann, Age of Spirituality, New York $1979, n^{\circ} 146$.

94 BMC Crete 61: 2; J.-N. Svoronos, Numismatique crétois du ve an ler siècle av. J.-C.. 1972, pl. 22: 35-37.

95 A.E. JACKSON, The Bronze Coinage of Gortyn, Numismatic Chronicle XI, 1971, 37 ss., pl. 12 , 1-4; J.-N. Sovoronos, Numismatique crétois du Ve au ler siécle av. J.-C., Bonn 1972, 153 ss., pl. XIII: $1-5,8-10,22-25$, XIV: $1-18$ y 20. 
que el árbol representado no es un plátano, sino un sauce, pero en todo caso y según $A$. Walzer, el árbol es símbolo de la tierra, Europa es una diosa de la tierra y Zeus es un dios del cielo ${ }^{96}$. Una posible representación de esta fase final del mito, por su estrecho paralelismo con el tipo monetal de Gortyna, se encuentra en una terracota ática de mediados del siglo $\mathrm{V}$ a.C., conservada en el Albertinum de Dresde, donde una joven se encuentra sentada sobre una roca, delante de un árbol, en actitud melancólica ${ }^{97}$ (Fig. 42).

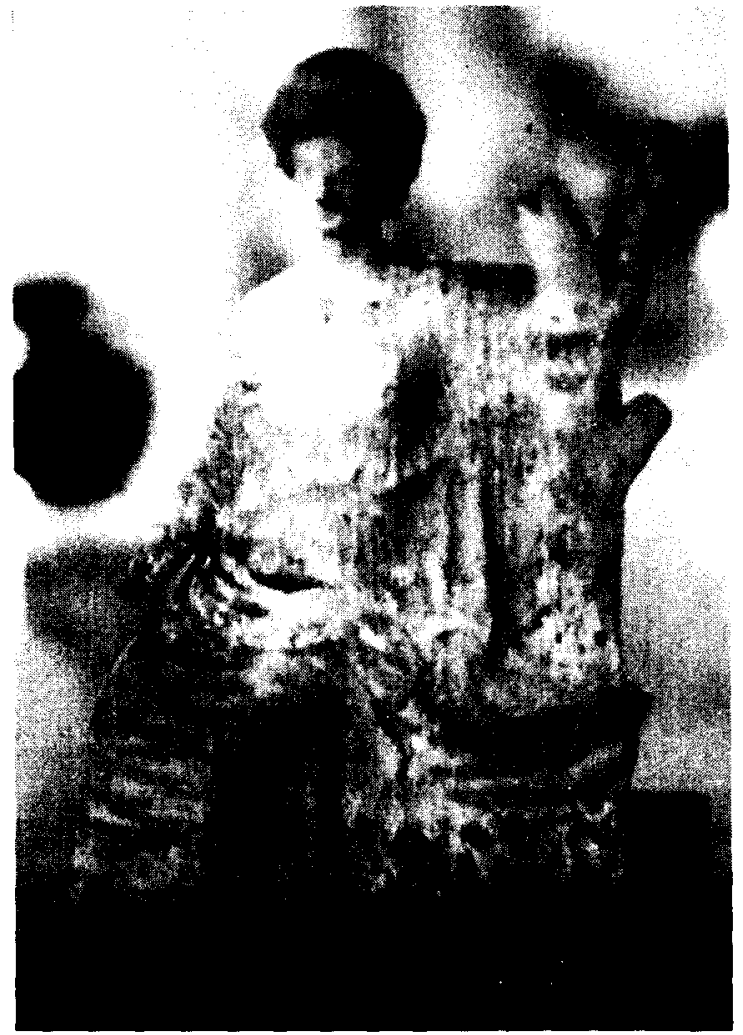

Figura 42. Terracota ática. Albertinum de Dresde (Foto G. LoPEz Monteagudo).

96 W. BuHLER, Europa, Ein Uberblick über die Zeugnisse des Mythos in der antiken Literatur und Kunst, München 1968, 49; A. WALZER, Die Europa in Baum. Neue Beiträge zur süddeutschen Münzkunde, 1953, 14-23.

97 Zv 1103, supuestamente procedente de Atenas, cf. P. HERMANN. Erwerbungen der Antikensammlungen in Deutschland. Dresden 1892, Arch. Anz. 1894, 31, n²2; F. Winter: Die Antiken Terracotten, If, Berlín, 1903, 107, $\mathrm{n}^{\circ}$ 10, tipo II, utilizado también en las representaciones de Afrodita desde finales del siglo $V$ hasta fines del II a.c. (cf. LIMC II, «Aphrodite», IVD). 


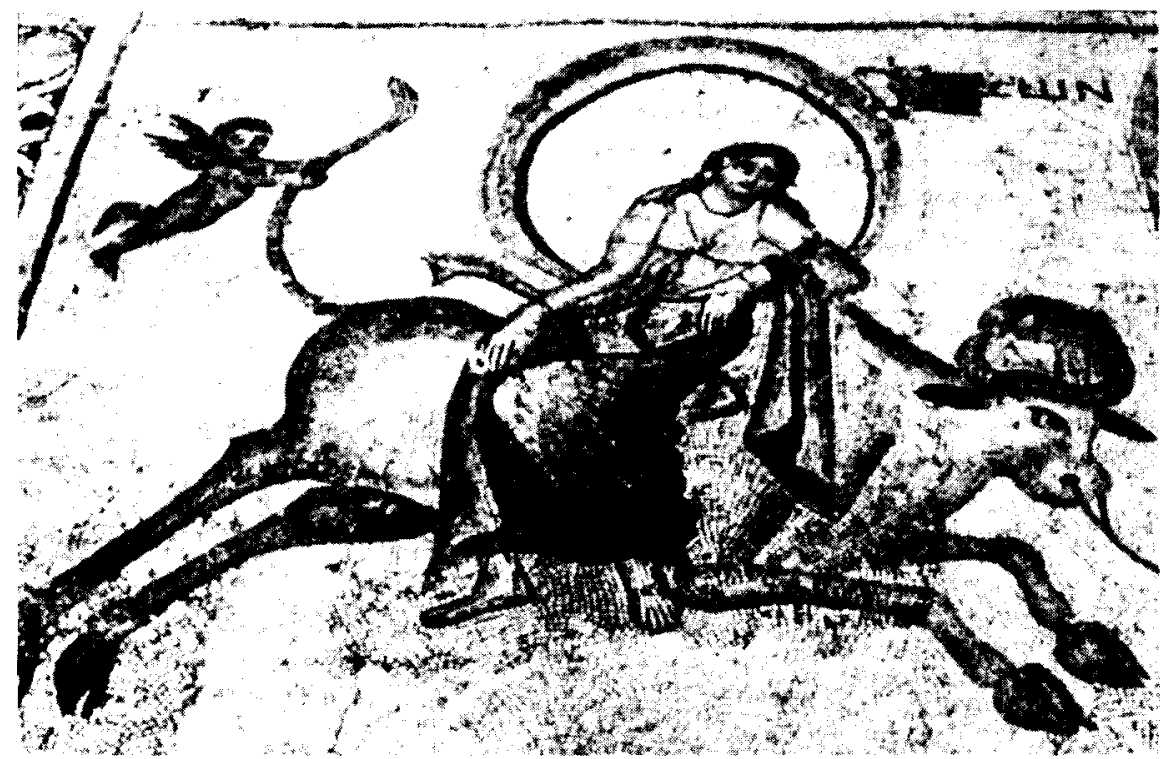

Figura 43. Mosaico de Sarrîn. Museo de Alepo.

El mismo momento ha quedado plasmado en el mosaico sirio de Sarrîn (Siria), de época ya tardía puesto que se fecha a lo largo del siglo VI ${ }^{98}$ (Fig. 43), según deja traslucir el aspecto de grandeza trágica de la heroína, aunque se trata de una representación única por aparecer contaminado este episodio con el inicio del rapto y la travesía marina, conjuntándose en una sola imagen varios facetas o etapas del relato mítico. Sin embargo, el pavimento sirio tiene la importancia de ser el único mosaico donde se refleja el carácter trágico que el mito de Europa adquiere en Horacio (Od. III 27) y de aumentar en tres el número de los procedentes del Oriente con este tema (Byblos y Antioquia), pero sobre todo ofrece un enorme interés iconográfico.

El toro va conducido por un eros que tira de la cuerda pasada por la nariz del animal, mientras que otro le sujeta por la cola, recordando los versos de Aquiles Tatius $(1$ 1,12) y de Nonnos (Dion. I 80-85; IV 295-302); los cuernos en forma de creciente sostienen un extraño objeto, que $O$. Wattel de Croizant cree poder identificar como una columna con su entablamento perteneciente al templo de Astarté en Sidón que, según el

98 J. BALty, La mosaïque de Sarrîn (Osrhoène), París, 1990, 47-50, pl. XX-XXI; WatTEL, 1995 , 204-207, pl. XXVI. 
testimonio de Aquiles Tatius ( 12 ) y corrobora una moneda de Heliogábalo emitida en la ciudad (vid. supra), estaba decorado con una pintura representando el rapto de Europa.

Europa va vestida con un largo peplos, detalle en el que insiste Nonnos (Dion. I 101-103) y que también lleva la princesa en los pavimentos de Corinto, fechado en la segunda mitad del siglo II d.C., Byblos, de época severiana, y Daphne, ya del siglo IV d.C. ${ }^{99}$; tanto su rostro como su actitud indolente, apoyada en la giba y no agarrada al cuerno del animal, revela la desesperanza y la tragedia del momento posterior al abandono, cuando ya se ha consumado la unión y Europa se reprocha el haber abandonado a su padre en un tono típico de las heroínas trágicas (Hor. od. III 27, 34-38), recordando la iconografía típica de ese episodio final, que aqui se ha contaminado con la travesía marina.

Finalmente, la representación de la ciudad de Sidón identificada por el letrero en griego, que recuerda muy de cerca a otras representaciones de ciudades en los mosaicos de Jordania ${ }^{100}$, haciendo referencia al punto de partida del relato mítico, constituye un hapax en las representaciones del rapto de Europa.

El mosaico de Sarrîn constituye un ejemplo de «representación abreviada", cuya contemplación invita a pasar de la lectura lineal a la exégesis alegórica o simbólica, de forma que la imagen escenificada contiene en sí misma los diversos episodios que componen el mito: ubicación del relato en Sidón donde tiene lugar el rapto; el viaje por el mar de Europa a lomos del toro/Zeus; la atracción amorosa personificada por los erotes, que conduce al hiéro gamos; y el abandono de la princesa sidonia por el dios.

Los detalles del mito sugieren la idea de una teogamia mediante la cual el dios del cielo se mezcla con la tierra penetrándola en primavera de un vigor nuevo, y es que la Europa cretense, originariamente llamada Hellotis ( vid. supra), es una divinidad telúrica cuya unión con Zeus, dios del cielo que en tiempos pre-griegos tenía forma de toro, era recordada anualmente en la fiesta de las Hellotia (Athen. XV 678a; Hesych. s.V. "Ellotia" y «Ellotis»; Steph. Byz. s.v. «Ellotia» y «Ellotis»), que cada primavera evocaba con carácter de resurrección y de apoteosis esta teogamia, coincidiendo

99 WATTEL, 1995, 171-173, 201-204, pl. XX-a y XXVa-b.

100 J. DECKERS, Tradition und adaptation. Bemerkungen zur Darstellung der christlichen Stadt, RM. XCV, 1988, 303 ss.; N. Duval, L'iconographie architecturale dans les mosaíques de Jordanie, en Mosaiques byzantines de Jordanie, Lyon, 1989, 207 ss.; M. PICCIRILlo, The Mosaics of Jordan, Amman, 1993. 
con la aparición en el cielo de la constelación del toro ${ }^{10 t}$. Sabido es que Zeus, en agradecimiento al toro cuya forma había adoptado para seducir a Europa, le convirtió en constelación pasando a formar parte de los signos del zodiaco (Apoll. Bibliot. III 1, 1-2; Nonn. Dion. I, 356-362), y precisamente el mito de Europa se introduce en el libro $V$ de los Fastos de Ovidio a propósito de este fenómeno astrológico que tiene lugar hacia el 14 de mayo (Ov. Fast. V 603-604).

En este contexto alegórico del hiéro gamos de Zeus con Europa en relación con la energía renovadora que la tierra recibe del cielo cada primavera, mediante la fusión de lo divino y lo humano como garantía de fecundidad y promesa de inmortalidad ${ }^{102}$, es fácil explicar que la figura de Europa se utilice en ocasiones para simbolizar a la Primavera, como pensamos que ocurre en uno de los medallones musivos que se conservan en el Museo Arqueológico de Córdoba, datado a fines del siglo II o a comienzos del III d.C. ${ }^{103}$ (Fig. 44). En él se ha figurado un busto femenino en posición de tres cuartos hacia la derecha, con los ojos levantados para arriba y el cabello peinado a grandes ondas a ambos lados de la cabeza; va vestida con un chiton de color verde que cubre el hombro izquierdo y se abrocha sobre el derecho, tras el cual asoma una cabeza de toro de color ocre oscuro y cornamenta negra. D. Fernández-Galiano interpretó el busto como una representación, un poco forzada por el espacio disponible, del mito de Europa ${ }^{104}$. Posteriomente G. López Monteagudo volvió sobre esta interpretación, basándose en el estudio del resto de los medallones conservados, concluyendo que en el pavimento cordobés las Estaciones no constituyen representaciones convencionales, sino que se han utilizado personajes míticos por su contenido alegórico en relación con las estaciones del año: Sileno/Otoño, Ganímedes/Verano, Europa/Primavera ${ }^{105}$.

101 Los datos más antiguos sobre las fiestas de las Hellotia los proporciona Seleucos, que relata cómo era llevada en procesión una guirnalda de mirto junto con los huesos de Europa, llamada anteriormente Hellotis. Europa se fusionó con Hellotia como emanación de la diosa-madre minoica, al igual que Démeter, estando documentado el culto a Démeter-Europa en Labadeia, cerca de Tebas (Paus. 9, 39,5), mientras que en Tebas el templo dedicado a Démeter Thesmophoros ocupaba el lugar del palacio de Cadmos, el hermano de Europa (Paus. 9, 16, 5). Hay que pensar que las hellotia eran festivales de mujeres, análogos a las thesmophoria, teniendo ambos por objeto la fertilidad de los cultivos, cf. R. F. WILLETTs, Cretan Cults and Festivals, London, 1962, 152 ss.

102 Sobre el carácter soteriológico del hiéro gamos, cf. R. TURCAN, Les sarcophages romains à représentations dionysiaques. Essai de chronologie et d'histoire religieuse. París, 1960, 529-534.

103 CMRE III, Madrid, 1981, 27, n¹1, lám. $12 \mathrm{c}$.

104 D. Fernandez-Galiano, Nuevas interpretaciones iconográficas sobre mosaicos hispanorromanos, Museos, 1, 1982, 19.

105 G. López Monteagudo, El mosaico de las Estaciones de Córdoba, Trab. Preh. 48, 1991, 365 ss. 


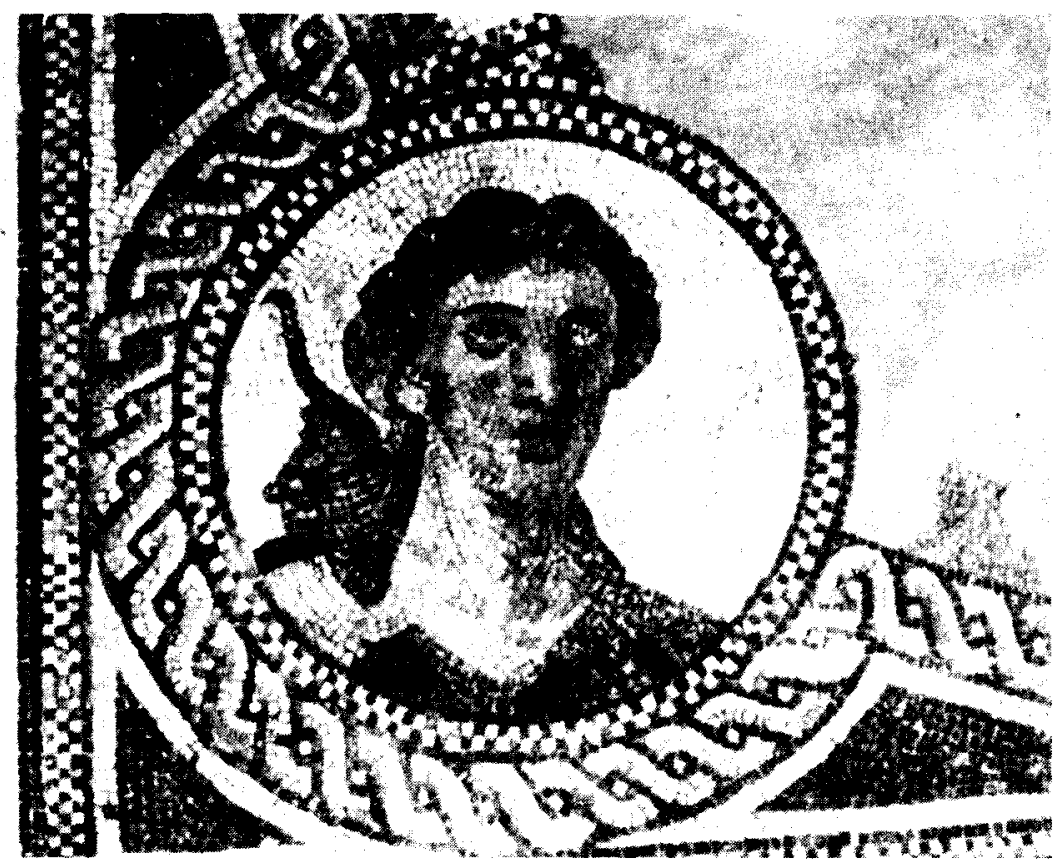

Figura 44. Mosaico de Córdoba. (Foto cortesia A. M. VICENT).

En realidad, la hierogamia de la princesa con Zeus a mediados del mes de rnayo, coincidiendo con la aparición en el cielo de la constelación del toro, tiene un alto contenido simbólico en relación con la primavera, por lo que no tiene nada de extraño que en el medallón de Córdoba se haya utilizado la figura de Europa, representada en forma de busto dentro de un medallón, que por su forma ocuparía uno de los ángulos del pavimento siguiendo la iconografía tradicional utilizada para representar a las estaciones, como alegoria de la Primavera con el toro como atributo. $Y$, por otra parte, no sería el único ejemplo de esa asimilación, ya que la citada figura de joven recogiendo flores en un cesto, procedente de Stabiae, se ha interpretado unas veces como Europa y otras como alegoría de la Primavera ${ }^{106}$; y la misma imagen del toro, que como signo astronómico aparece en el calendario romano a mediados del mes de mayo, se ha utilizado en diversas ocasiones como símbolo de la estación primaveral; con

106 K. SCHEFOLD, La peinture pompéianne, Essai sur l'évolution de sa signification, Col. Latomus 108, Bruxelles, 1972, 165-166; A. MAIUfI, La peinture romaine, Genève, 1953, 83. 
este carácter aparece en los mosaicos de Saint Romain-en-Gal, del primer cuarto del siglo III d.C., y de Dair Solaib fechado ya en la segunda mitad del $V$ d.C., así como en un sarcófago romano de la segunda mitad del siglo III d.C., donde se ha figurado a la Primavera como una joven con cesto de flores acompañada de un toro ${ }^{107}$. Igualmente, en los mosaicos hispanos de Hellín y Fraga, datados en la primera mitad del siglo III y en la segunda del IV d.C. respectivamente, la figura del toro se ha utilizado para representar a los meses de abril y mayo ${ }^{108}$.

Esa conexión entre el mito de Europa y la estación primaveral queda también patente en las alusiones que se hacen a las flores en distintas representaciones: Europa aparece recogiendo flores en un cesto en la pintura de Stabiae, fechada en la mitad del siglo I d.C., y en monedas de Tyro de mediados del III d.C., evocando los versos de Moschos (II 34, 37 62). El cesto lleno de flores se documenta, asimismo, en cerámica ática de figuras negras, de comienzos del siglo $\mathrm{V}$ a.C., en un vaso pintado del siglo III d.C. ${ }^{109}$, y en el mosaico argelino de Djemila, ya del IV d.C., que representa el viaje marino con Europa sentada sobre el toro, el cual vuelve la cabeza hacia el cesto de flores que le ofrece la joven. Europa y sus compañeras aparecen adornando al toro con guirnaldas de flores en los mosaicos de Ouled Agla y de Keynsham, ambos fechados en el siglo IV d.C. Durante la travesía marina la princesa sidonia lleva en su mano una flor o una guirnalda, evocando los versos de Ovidio (Met. II 869-871) y de Moschos (II 30-99), que hacen referencia a la ocupación de la princesa en el momento del rapto.

Los documentos arqueológicos ofrecen algunas variantes iconográficas en cuanto al tipo de atributo que unas veces es una flor, como en la citada hydria de Caere del Museo del Louvre o en la lucerna de Bulla Regia, datada en 150-200 d.C. ${ }^{110}$, o un ramo de flores en el perdido mosaico de Naix-aux-Forges, del siglo II-III d.C. ${ }^{111}$; una guirnalda sostiene Europa en la terracota hispana de Sisapo, que se fecha en la primera mitad del siglo I d.C., y en el mosaico de Oudna, de mediados del III d.C.; o también una corona de flores, tal como aparece en el camafeo del Cabinet des Médailles de Paris, fechado en el siglo I-II d.C. (Fig. 45), en sigillata de

\footnotetext{
107 RGMG III/I, 1981, 217-225, n 368; G.M.A. HANFMANN, The Season Sarcophagus in Dumbarton Oaks, Harvard, 1951, 154, no 192, 187, A-6.

109 CMRE X, 1989, 49-56, n 39; D. FernAndez-Galiano, El Calendario romano de Fraga, BSAA $52,1986,179-180$.

109 LIMC IV, "Europe l", nº 15, 36, 38 y 39.

110 P. Gauckler, Catalogue du Musée Alaoui, Paris, 1897, 162, nº 127.

"1) WATTEL, 1995, 141, fig. 22.
} 


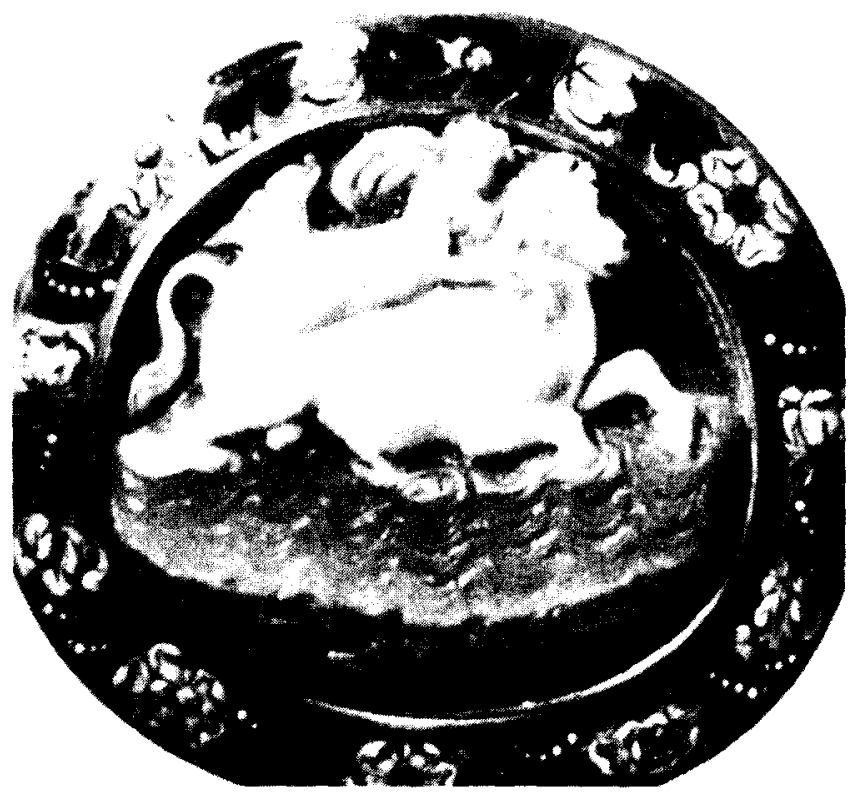

Figura 45. Camafeo. Cabinet des Médailles de París.

fines del siglo II d.C. y en cerámica de Andújar ${ }^{112}$ (Fig. 16, 5). Europa sentada sobre el toro y llevando flores en su falda, a la manera de Proserpina y sus compañeras (Ovid. Fast. IV 431-436), se representa en un relieve itálico en mármol del siglo I-II d.C. ${ }^{113}$. La pradera florida está presente en el mosaico de Cannes, fechado en el siglo I d.C., y en los pavimentos hispanos de Mérida y de Fernán-Núñez, que se fechan a mediados del siglo II y a comienzos del III d.C. respectivamente. Pero las flores tienen un doble carácter funerario y de fertilidad, y por consiguiente su presencia puede tomarse tanto como preludio de la muerte como del matrimonio ${ }^{114}$.

La insistente evocación de las flores por parte de los poetas y la hierogamia de la princesa con Zeus a mediados del mes de mayo, coincidiendo con la aparición en el cielo de la constelación de Taurus, tienen un alto contenido simbólico en relación con la estación primaveral y así ha quedado reflejado en numerosas ocasiones. Pensamos que esta presencia

\footnotetext{
112 F. MAYET, Les céramiques sigillées hispaniques, Paris, 1984, pl. LIV. 337 y 338

113 LIMC IV, "Europe I", no 171.

114 A. MotTE, Prairies et jardins de la Grèce antique, Bruxelles 1874, 38-47.
} 
reiterativa de las flores en los variados documentos arqueológicos se ha hecho de forma deliberada con objeto de evocar no solo la actividad de la princesa sidonia, ocupada en recoger flores junto a sus compañeras en las playas de Tyro o de Sidón, en el momento en el que tiene lugar el rapto, sino también como alegoría de la estación primaveral, por su carácter de diosa madre asimilada a veces también a Ceres, como se atestigua en una gema de Beocia donde aparece Ceres-Europa montada sobre el toro, sosteniendo rosas y una cornucopia ${ }^{115}$, y a Afrodita. Afrodita, como versión occidental de la diosa semita de la fertilidad Astarté, comparte con Europa varios rasgos cultuales e iconográficos: sus plantas son la rosa y el mirto (Herod. 2, 135); el tipo iconográfico de diosa montada sobre el toro se utiliza en las representaciones tempranas de ambas; la iconografía del velo arqueado sobre la cabeza se utiliza también en las representaciones de Afrodita en su carácter astral como diosa de los planetas, así como montada sobre el cisne, el macho cabrio o el delfín ${ }^{116}$. No hay que olvidar que Europa es una divinidad oriental asimilada a Astarté y como tal participa de los cultos agrarios de fertilidad y de fecundidad que juegan un papel preponderante en las religiones semíticas, caracterizados por rituales de fuerte contenido sexual y erótico, como son la hierogamia, la prostitución sagrada y la hydrophoria.

En otra ocasión hemos tenido ocasión de apuntar que las diferencias entre los tipos iconográficos en la representación del rapto de Europa están condicionadas por el soporte y la cronología ${ }^{117}$. La naturaleza y el tamaño de aquel supone evidentemente una limitación a la escena representada y por consiguiente es lógico que en escultura de bulto redondo en terracotta y bronce, así como en monedas, gemas, marcas de entalles en sigillatas, discos de bronce o espacios musivos reducidos, los episodios del mito se simplifiquen al máximo, prescindiéndose de personajes y elementos adiccionales como pueden ser los erotes o los peces, e incluso a veces del mismo velo arqueado sobre la cabeza de Europa, de forma que las flores, guirnaldas y coronas se convierten en los únicos detalles iconográficos que el artista destaca en el contexto alegórico del mito. Por el contrario, en la pintura vascular y parietal y en las superficies musivas se hace por lo general un gran alarde narrativo, deteniéndose el autor en la

115 E. M. SAUnders, Goddess Riding a Goat-bull Monster: A Ceres Zodiac Gem from the Walters Art Gallery, Journal of the Walters Ant Gallery, 49-50, 1991-92, 7 ss.

116 LIMC IV, "Europe I», 76 ss.; LIMC II, “Aphrodite" IIIA 6c, tipo Urania; IVE.

17 G. López Monteagudo, M. P. SAN Nicolás Pedraz, La iconografía del Rapto de Europa en el Mediterráneo occidental. A propósito de una lucerna del Museo de Sassari, L'Africa romana VIII, Sassari, 1991, 1.015-1.017 
representación de todo tipo de detalles, como puede ser el paisaje terrestre, las compañeras de Europa, los erotes, la fauna marina o los personajes que intervienen en el relato mítico. Todo o casi todo cabe en la superficie del cuadro, en el que en ocasiones se procede por alusiones, produciéndose una contaminación con otros ciclos de la mitología, como los Amores de Júpiter o el thiasos marino y el dionisiaco.

En lo referente a las escenas musivas, la cronologia y la distribución geográfica juegan igualmente un papel importante en las variantes iconográficas del rapto de Europa, según han demostrado los estudios de $O$. Wattel-de-Croizant. Piensa esta autora que en los mosaicos del siglo III d.C. existe un desarrollo progresivo del erotismo hasta que en el siglo IV d.C. el mito se convierte en una simple parodia como consecuencia del cambio ideológico que se opera con la introduccción del cristianismo. Por otra parte, mientras que en Hispania, Galia y Oriente predominan las representaciones bastantes simplificadas del relato mitológico, en Italia, Africa y Britania abundan las composiciones grandiosas con inclusión de elementos fantásticos que remontan a los vasos apulios de fines del siglo IV a.C., inspirados a su vez en obras pictóricas monumentales que ya eran célebres en su época ${ }^{118}$.

En cuanto al contenido alegórico de las representaciones del rapto de Europa, O. Wattel de-Croizant afirma que en las provincias de Africa, Galia, España, Grecia y Panonia, la travesia marina de Europa se habia convertido, en los siglos 11 y III d.C., en una escena decorativa banalizada. Añade la $A$. que, por su contaminación con el thiasos marino desde finales del siglo III y sobre todo a lo largo de los siglos IV y $\mathrm{V}$, en las mentalidades colectivas del final del imperio el rapto de Europa no solamente aparece como una aventura galante, sino como una alegoría de la muerte y un tema de salud, ya que la hierogamia constituía el desenlace feliz del periplo ${ }^{119}$.

Diferimos de la propuesta de $O$. Wattel-de Croizant acerca del significado funerario que la travesía marina tiene como superación del espacio existente entre el mundo de los vivos y de los muertos, convirtiéndose el mito en símbolo del camino que conduce a la inmortalidad a través de la exaltación del amor ${ }^{120}$. Y aunque no podamos prescindir del simbolismo escatológico de las escenas del rapto de Europa en aquellos objetos que

11 O. DE CRolzAnt, Les représentations d'Europe en Afrique, BAC 8, 1972, 51; O. WATtEL-DE Croizant, A propos du mythe d'Europe, Caesarodumum XV bis, 1980, 429.

119 WATTEL, 1995, 5, 239-244.

120 WATTEL, $1995,5,245-252$. 
por su misma naturaleza, como las estelas funerarias, o por su procedencia de necrópolis, como ocurre con las lucernas y algunas terracotas, se encuentran insertos en un contexto de naturaleza claramente funeraria, sin embargo pensamos que su utilización en ambientes domésticos o termales, dentro de programas iconográficos de thiasos marino o dionisiaco, donde las parejas amorosas constituyen un himno a la fecundidad como garantía permanente de la vida, se halla más en conexión con el carácter ancestral de la princesa sidonia, como divinidad astral y diosa madre de origen oriental, que reúne los atributos de fertilidad y prosperidad de las diosas del amor desde Astarté a Afrodita. $Y$ este carácter se acentúa en aquellas regiones como Hispania donde existía un fuerte arraigo del culto oriental a Astarté desde la época de las colonizaciones ${ }^{121}$.

121 Sobre este particular cf. G. Lopez Monteagudo-M. P. San Nicolás Pedraz, Astarté-Europa en la Peninsula Ibérica. Un ejemplo de interpretatio romana, Homen. M. Fernández-Miranda (en prensa). 